\title{
Influence of Cyclopentadienyl Ring-Tilt on Electron Transfer Reactions: Redox-Induced Reactivity of Strained [2] and [3]Ruthenocenophanes
}

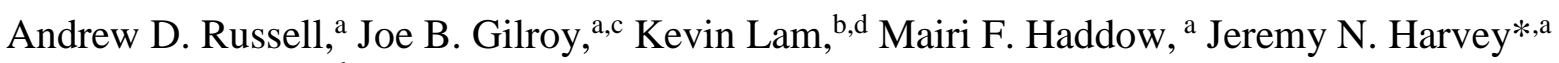
William E. Geiger*,b Ian Manners*,a

${ }^{\text {aS }}$ chool of Chemistry, University of Bristol, Bristol, BS8 1TS, UK.

${ }^{b}$ Department of Chemistry, University of Vermont, Burlington, Vermont, 05405-0125, USA.

'Present Address: Department of Chemistry, University of Western Ontario, 1151, Richmond Street, London, ON, Canada, N6A 5B7

dPresent Address: Nazarbayev University, School of Science and Technology, 53 Kabanbay Batyr Ave, Block 7 , Office 7107, 0100000, Astana, Republic of Kazakhstan

\section{ABSTRACT}

In contrast to ruthenocene $\left[\mathrm{Ru}\left(\eta^{5}-\mathrm{C}_{5} \mathrm{H}_{5}\right)_{2}\right]$ and dimethylruthenocene $\left[\mathrm{Ru}\left(\eta^{5}-\mathrm{C}_{5} \mathrm{H}_{4} \mathrm{Me}\right)_{2}\right](7)$ chemical oxidation of highly strained, ring-tilted [2]ruthenocenophane $\left[\mathrm{Ru}\left(\eta^{5}-\mathrm{C}_{5} \mathrm{H}_{4}\right)_{2}\left(\mathrm{CH}_{2}\right)_{2}\right]$ (5) and slightly strained [3]ruthenocenophane $\left[\mathrm{Ru}\left(\eta^{5}-\mathrm{C}_{5} \mathrm{H}_{4}\right)_{2}\left(\mathrm{CH}_{2}\right)_{3}\right]$ (6) with cationic oxidants containing the non-coordinating $\left[\mathrm{B}\left(\mathrm{C}_{6} \mathrm{~F}_{5}\right)_{4}\right]^{-}$anion was found to afford stable and isolable metal-metal bonded dicationic dimer salts $\left[\mathrm{Ru}\left(\eta^{5}-\mathrm{C}_{5} \mathrm{H}_{4}\right)_{2}\left(\mathrm{CH}_{2}\right)_{2}\right]_{2}\left[\mathrm{~B}\left(\mathrm{C}_{6} \mathrm{~F}_{5}\right)_{4}\right]_{2}(\mathbf{8})$ and $\left[\mathrm{Ru}\left(\eta^{5}-\mathrm{C}_{5} \mathrm{H}_{4}\right)_{2}\left(\mathrm{CH}_{2}\right)_{3}\right]_{2}\left[\mathrm{~B}\left(\mathrm{C}_{6} \mathrm{~F}_{5}\right)_{4}\right]_{2}(\mathbf{1 7})$, respectively. Cyclic voltammetry and DFT studies indicated that the oxidation potential, propensity for dimerization, and strength of the resulting $\mathrm{Ru}-\mathrm{Ru}$ bond is strongly dependent on the degree of tilt present in $\mathbf{5}$ and $\mathbf{6}$ and thereby degree of exposure of the Ru center. Cleavage of the $\mathrm{Ru}-\mathrm{Ru}$ bond in $\mathbf{8}$ was achieved through reaction with the radical source $\left[\left(\mathrm{CH}_{3}\right)_{2} \mathrm{NC}(\mathrm{S}) \mathrm{S}-\mathrm{SC}(\mathrm{S}) \mathrm{N}\left(\mathrm{CH}_{3}\right)_{2}\right]$ (thiram), affording unusual dimer $\left[\left(\mathrm{CH}_{3}\right)_{2} \mathrm{NCS}_{2} \mathrm{Ru}\left(\eta^{5}-\mathrm{C}_{5} \mathrm{H}_{4}\right)\left(\eta^{3}-\mathrm{C}_{5} \mathrm{H}_{4}\right) \mathrm{C}_{2} \mathrm{H}_{4}\right]_{2}\left[\mathrm{~B}\left(\mathrm{C}_{6} \mathrm{~F}_{5}\right)_{4}\right]_{2} \quad$ (9) through a haptotropic $\eta^{5}-\eta^{3}$ ring-slippage followed by an apparent $[2+2]$ cyclodimerization of the cyclopentadienyl ligand. Analogs of possible intermediates in the reaction pathway $\left[\mathrm{C}_{6} \mathrm{H}_{5} \mathrm{ERu}\left(\eta^{5}-\mathrm{C}_{5} \mathrm{H}_{4}\right)_{2} \mathrm{C}_{2} \mathrm{H}_{4}\right]\left[\mathrm{B}\left(\mathrm{C}_{6} \mathrm{~F}_{5}\right)_{4}\right][\mathrm{E}=\mathrm{S}$ (15) or Se (16)] were synthesized through reaction of 8 with $\mathrm{C}_{6} \mathrm{H}_{5} \mathrm{E}-\mathrm{EC}_{6} \mathrm{H}_{5}(\mathrm{E}=\mathrm{S}$ or $\mathrm{Se})$. 


\section{INTRODUCTION}

Strained $[n]$ metallocenophanes $\mathbf{1},{ }^{1}$ and their analogues containing other $\pi$-hydrocarbon ligands, ${ }^{2}$ are a class of organometallic molecules that have received widespread attention due to their interesting structures and reactivity. Distortion of the normally parallel cyclopentadienyl ( $\mathrm{Cp}$ ) rings (or their $\pi$-coordinated counterparts) to a tilted orientation (as defined by $\alpha$ ) (Figure 1 ) occurs when the ansa linkage is sufficiently short $(n \leq 2)$. For $[n]$ metallocenophanes containing more than four d electrons, significant tilt angles $(\alpha=14-$ $33^{\circ}$ ), are associated with high-energy, distorted structures, ${ }^{3}$ where the inherent ring-strain can be employed as a thermodynamic driving force for ring-opening reactions. ${ }^{4}$

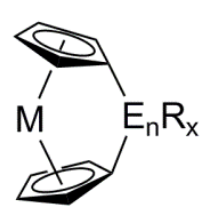

1

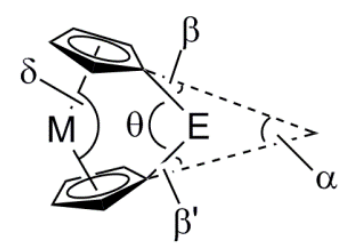

$\beta^{\prime}$

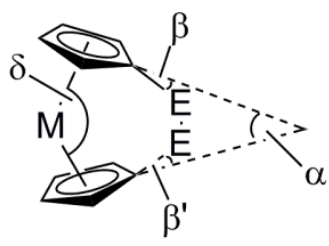

Figure 1: Structural metrics of $[n]$ metallocenophanes

Significantly, the release of ring-strain in $[n]$ metallocenophanes $\mathbf{1}$ can be exploited in the preparation of polymetallocenes 2 (Figure 2), incorporating metallocene units in the mainchain, via ring-opening polymerization (ROP) reactions. ${ }^{5}$ The most extensively studied system involves strained sila[1]ferrocenophanes $\left(\mathbf{1}, \mathrm{M}=\mathrm{Fe}, \mathrm{E}_{\mathrm{n}} \mathrm{R}_{\mathrm{x}}=\mathrm{SiRR}\right.$ '), which afford polyferrocenylsilanes $\left(2, \mathrm{M}=\mathrm{Fe}, \mathrm{E}_{\mathrm{n}} \mathrm{R}_{\mathrm{x}}=\mathrm{SiRR}\right.$ ') upon ROP. The interesting properties of these metallopolymers, which complement those of their all-organic counterparts, has resulted in their use in a diverse range of applications, including as catalyst and magnetic ceramic precursors, ${ }^{6}$ etch resists, ${ }^{7}$ the redox-active component of photonic crystal displays, ${ }^{8}$ redox-active films, microcapsules and microspheres, ${ }^{9}$ and self-assembled, nanostructured materials. $^{10}$ 


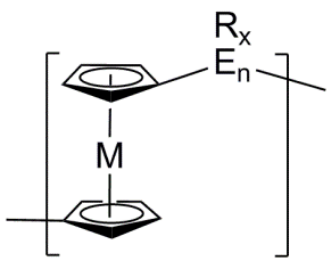

2

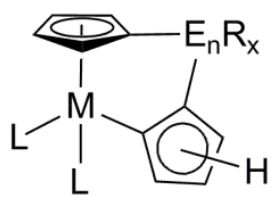

3

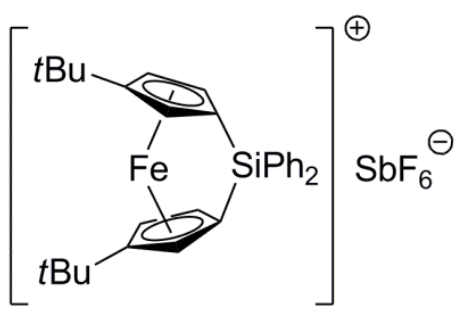

$4^{+}$

$\mathrm{M}: \mathrm{Fe}, \mathrm{Ru}$

$\mathrm{L}=\mathrm{PR}_{3}, \mathrm{P}(\mathrm{OR})_{3}$

Figure 2. Polymetallocene 2, ring-slipped [ $n]$ metallocenophane $\mathbf{3}$ and [1]ferrocenophanium ion $\mathbf{4}^{+}$

The relative ease of synthesis and propensity for ring-opening reactions of sila[1]ferrocenophanes has made them the focus for the majority of $[n]$ metallocenophane research. However, through variation of the incorporated metal atom, ${ }^{11}$ and bridging moiety $\left(\mathrm{E}_{n} \mathrm{R}_{\mathrm{x}}\right)$, a wide range of other $[n]$ metallocenophanes has also been prepared. ${ }^{1 \mathrm{a}, 2 \mathrm{~d}, 1 \mathrm{~b}-\mathrm{i}}$ The known reactivity modes of $[n]$ metallocenophanes involve a variety of bond-cleavage pathways whose nature and location is dictated by the identity of the metal and bridging moiety. For example, cleavage of the polarized $\mathrm{C}_{\mathrm{ipso}}-\mathrm{E}$ bond in sila[1]ferrocenophanes, with initiation of ROP, can be induced via the addition of anionic reagents such as $n \mathrm{BuLi},{ }^{12}$ or transition metal catalysts. ${ }^{13}$ Oxidative-insertion of metal fragments into this bond has also been demonstrated. ${ }^{14}$ Cleavage of the E-E bridge bond in [2]metallocenophanes has been implicated in ring-opening reactions, including homolytic bridge cleavage ${ }^{15}$ and insertion of main group elements or metal fragments. ${ }^{16}$

In contrast, UV-irradiation of $[n]$ ferrocenophanes results in a selective weakening of the $\mathrm{M}-\mathrm{Cp}$ bond and subsequent cleavage in the presence of suitable initiators such as $\mathrm{Na}_{2}\left[\mathrm{C}_{5} \mathrm{H}_{5}\right]$ enables ROP under mild conditions. ${ }^{17}$ Haptotropic $\eta^{5}-\eta^{1}$ ring-slippage of the $\mathrm{Cp}$ rings has been reported for several [1]- and [2]metallocenophanes through the addition of phosphine donors (usually under UV-irradiation) to afford species such as $\mathbf{3}$ (Figure 2). ${ }^{18}$ Recent investigations illustrated how changes in the redox state of $[n]$ metallocenophanes can alter their ansa structure and electron distribution, as observed through the synthesis and reactivity 
of a [1]ferrocenophanium ion $\mathbf{4}^{+}$(Figure 2). ${ }^{19}$ In addition, several other reactivity modes for strained $[n]$ metallocenophanes that involve reactivity at the metal centre have been identified. ${ }^{20,11 \mathrm{~d}}$

The well-known redox properties of ferrocenes, with readily accessible and stable redox states $\left(\mathrm{Fe}^{\mathrm{II}} / \mathrm{Fe}^{\mathrm{III}}\right)$, has resulted in their employment as a standard reference for electrochemical studies, ${ }^{21}$ as well as many other applications. ${ }^{22,9 c, 8}$ The redox properties of strained $[n]$ ferrocenophanes ${ }^{23,17 c}$ have also been studied and, except in the case of highly strained examples, are similar to those observed for their unstrained analogues. ${ }^{12,17 \mathrm{~b}}$ Investigations into the redox chemistry of ruthenocenes, in the presence of electrolytes containing weaklycoordinating anions, have revealed behavior that is more complex than that of simple ferrocene derivatives, with evidence of further reactivity occurring upon oxidation. ${ }^{24}$ To date the electrochemical properties of strained ruthenocenophanes are unexplored, apart from the case of the slightly strained, sterically-congested, electron-rich permethylated [3]ruthenocenophane $\left[\mathrm{Ru}\left(\eta^{5}-\mathrm{C}_{5} \mathrm{Me}_{4}\right)_{2}\left(\mathrm{CH}_{2}\right)_{2}\right]$. This species was found to undergo a reversible one-electron oxidation in $\mathrm{CH}_{2} \mathrm{Cl}_{2}$, but afforded the $\mathrm{Ru}^{\mathrm{IV}}$ solvent adduct via a two electron oxidation, when the cyclic voltammetry was conducted in $\mathrm{MeCN}$ (Scheme 1). ${ }^{20 a}$

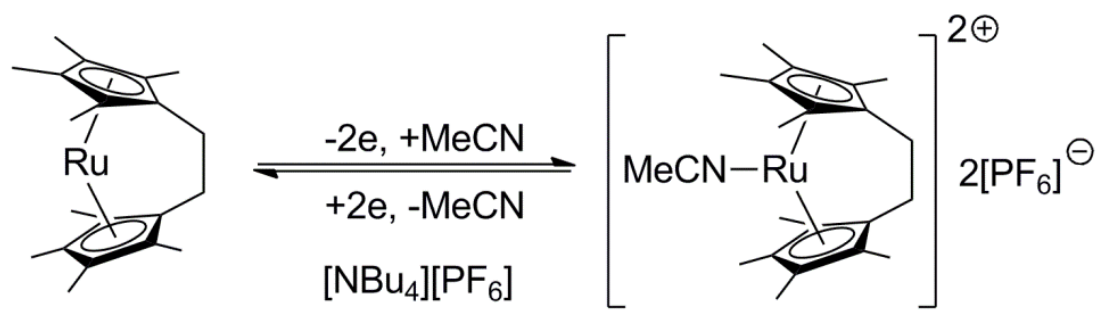

Scheme 1. Cyclic voltammetry of octamethyl dicarba[2]ruthenocenophane in MeCN.

In this paper we report full detailed studies of the redox chemistry of highly strained [2]ruthenocenophane 5, slightly strained [3]ruthenocenophane $\mathbf{6}$, and the unstrained analog dimethylruthenocene 7 (Figure 3) and describe the formation of novel dimerization products with $\mathrm{Ru}-\mathrm{Ru}$ bonds for the former two species. ${ }^{25} \mathrm{We}$ also include electrochemical and 
computational investigations into the effect of tilt on both the oxidation potential and propensity for dimerization. Our studies also reveal an additional unprecedented reactivity mode for [n]metallocenophanes, namely $\eta^{5}-\eta^{3}$ haptotropic ring-slippage and dimerization of the $\mathrm{Cp}$ ring with $\mathrm{C}-\mathrm{C}$ bond formation.

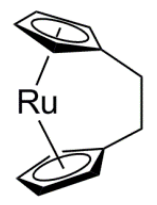

5

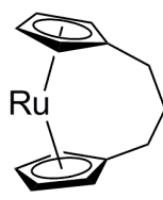

6

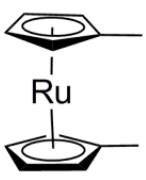

7

Figure 3: Dicarba[2]ruthenocenophane 5, tricarba[3]ruthenocenophane 6 and dimethylruthenocene 7

\section{RESULTS AND DISCUSSION}

1) Electrochemical Studies of [2]Ruthenocenophane 5: Synthesis and Characterization of Dicarba[2]ruthenocenophanium Dimer 8

The redox properties of dicarba[2]ruthenocenophane $5\left[\alpha=29.6(5)^{\circ}, \mathrm{C}-\mathrm{C}\right.$ bridge $=$ 1.549(9) $\AA$ ], prepared utilizing a previously published "fly-trap" procedure involving the reaction of $\mathrm{Li}_{2}\left[\left(\mathrm{C}_{5} \mathrm{H}_{4}\right)_{2}\left(\mathrm{C}_{2} \mathrm{H}_{4}\right)\right]$ with $\mathrm{RuCl}_{2},{ }^{11 \mathrm{a}}$ were investigated using cyclic voltammetry $(\mathrm{CV})$ in the presence of the weakly-coordinating supporting electrolyte $[n \mathrm{Bu} 4 \mathrm{~N}]\left[\mathrm{B}\left(\mathrm{C}_{6} \mathrm{~F}_{5}\right)_{4}\right]{ }^{26}$ Under identical conditions, $\mathrm{CV}$ studies of unstrained analog ruthenocene, $\left[\mathrm{Ru}\left(\eta^{5}-\mathrm{C}_{5} \mathrm{H}_{5}\right)_{2}\right]$ $\left(\mathrm{RuCp}_{2}\right)$, displayed a reversible oxidation wave $\left(\mathrm{E}_{1 / 2}=0.41 \mathrm{~V}\right.$ vs. $\mathrm{FcH}$, where $\mathrm{FcH}=$ $\mathrm{FeCp}_{2}{ }^{0 /+}$ ) corresponding to the formation of the ruthenocenium ion, $\left[\mathrm{RuCp}_{2}\right]^{+} .{ }^{22 \mathrm{~b}}$ In situ voltammetry and NMR spectroscopy demonstrated that this cation exists in equilibrium with the metal-metal bonded dimer dication, $\left[\mathrm{Ru}_{2} \mathrm{Cp}_{4}\right]^{2+} \cdot{ }^{24 \mathrm{~d}}$ Contrastingly, $\mathrm{CV}$ scans of 5 (at $0.2 \mathrm{~V}$ $\mathrm{s}^{-1}$ ) show that it undergoes an irreversible one-electron oxidation (Figure 1, $\mathrm{E}_{\mathrm{pa}}=0.05 \mathrm{~V} v \mathrm{~s}$. $\mathrm{FcH})$ giving a single electroactive product having an irreversible reduction at $\mathrm{E}_{\mathrm{pc}}=-0.33 \mathrm{~V}$ vs. $\mathrm{FcH}$ (Figure 4). Bulk anodic electrolysis $\left(\mathrm{E}_{\mathrm{appl}}=0.4 \mathrm{~V}\right)$ confirmed the one-electron oxidation of $\mathbf{5}$, its exclusive conversion to the single product, and the subsequent quantitative reduction of that product $\left(E_{\text {appl }}=-0.7 \mathrm{~V}\right)$ back to 5 . These observations, in concert with the 
literature precedent for the dimerization of ruthenocene, suggested that the metal-metal bonded dicarba[2]ruthenocenophanium dimer dication $\mathbf{8}$ is the product afforded upon oxidation of $\mathbf{5}$.

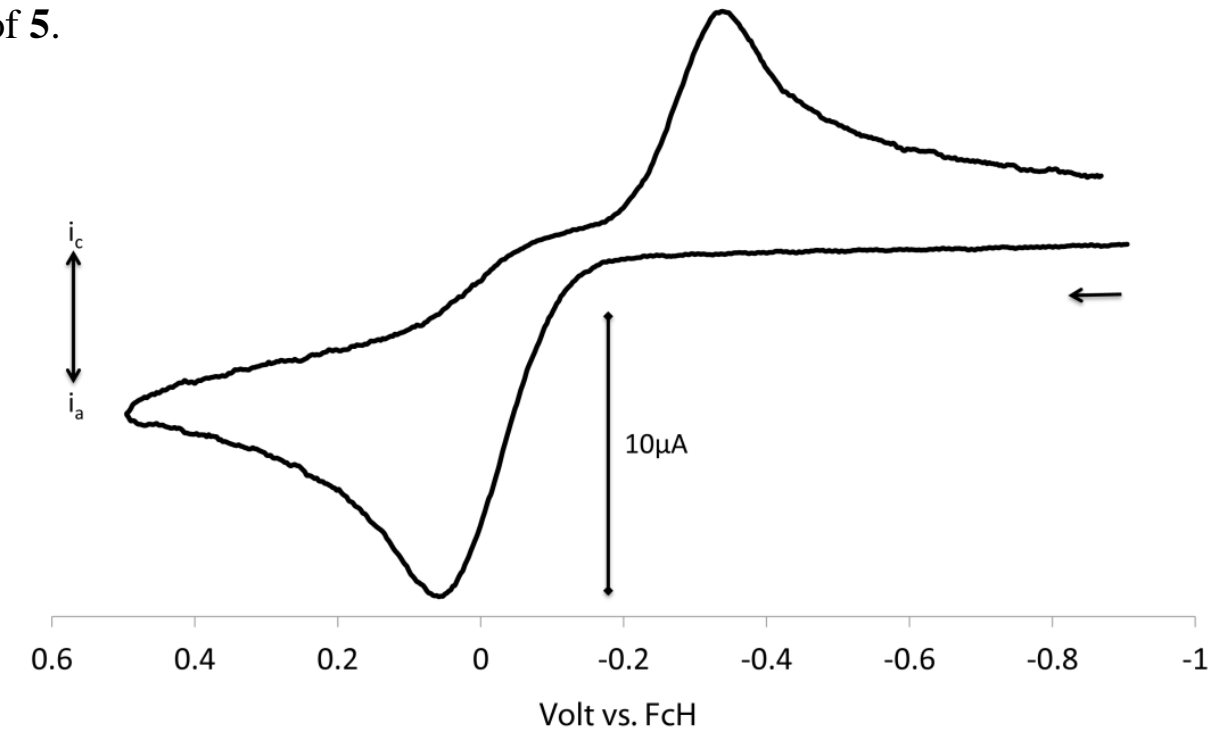

Figure 4: Cyclic voltamogram of a $\mathrm{CH}_{2} \mathrm{Cl}_{2}$ solution of 5 (ca. $1 \mathrm{mM}$ analyte, $0.05 \mathrm{M}$ $\left[n \mathrm{Bu}_{4} \mathrm{~N}\right]\left[\mathrm{B}\left(\mathrm{C}_{6} \mathrm{~F}_{5}\right)_{4}\right]$, scan rate $\left.=0.2 \mathrm{~V} \mathrm{~s}^{-1}\right)$.

Although the irreversibility of the oxidation precludes a precise determination of the half cell potential $\left(\mathrm{E}_{1 / 2}\right)$ for the $\mathbf{5}^{0 /+}$ couple, a value of approximately $0 \mathrm{~V} v s$. $\mathrm{FcH}$ is a reasonable estimate. In contrast to the highly concentration and temperature-dependent voltammetry of ruthenocene, ${ }^{24 \mathrm{~b}, 24 \mathrm{~d}}$ the redox properties of $\mathbf{5}$ vary little with changes in the medium. Chemical reversibility of the $\mathbf{5}^{0 /+}$ couple was not observed even at relatively low analyte concentrations (e.g., $10^{-4} \mathrm{M}$ ), suggesting formation of a dimer dication that is thermodynamically more highly favoured than in the case of the ruthenocenium ion.

Chemical oxidation of dicarba[2]ruthenocenophane $\mathbf{5}$ was conducted to further characterize the product identified through the electrochemical studies. To this end, reaction of a stoichiometric quantity of acetylferrocenium tetra(pentafluorophenyl)borate $\left[\mathrm{FcCOCH}_{3}\right]\left[\mathrm{B}\left(\mathrm{C}_{6} \mathrm{~F}_{5}\right)_{4}\right],{ }^{21}$ with dicarba[2]ruthenocenophane 5 (in $\mathrm{CH}_{2} \mathrm{Cl}_{2}$ ) resulted in the immediate generation of a dark green precipitate (Scheme 2). Following filtration and 
removal of residual solvent in vacuo, dication $\mathbf{8}$ was isolated as a dark, microcrystalline, green solid (74\% yield). ${ }^{27}$

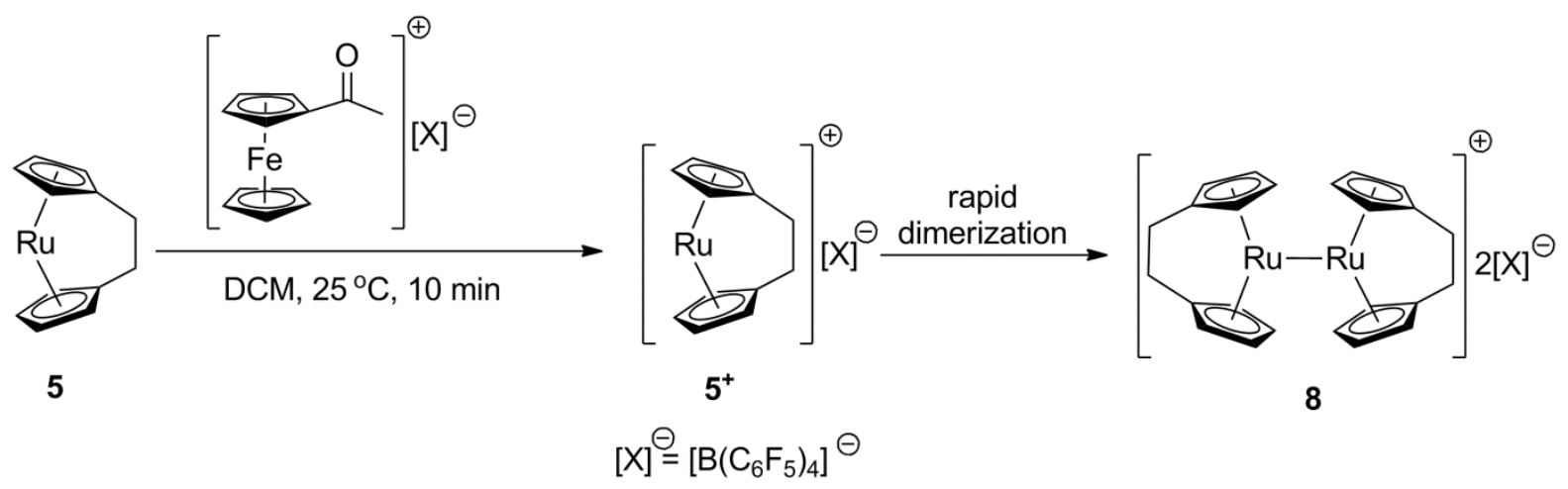

Scheme 2: Synthesis of dimer 8 via chemical oxidation of dicarba[2]ruthenocenophane 5.

Dimer 8 was analysed by ${ }^{1} \mathrm{H}$ NMR and ${ }^{13} \mathrm{C}$ spectroscopy which observed resonances assigned to both the $\eta^{5}-\mathrm{C}_{5} \mathrm{H}_{4}$ rings and $\left(\mathrm{CH}_{2}\right)_{2}$ bridge (see SI for details). Visable spectroscopy studies of $\mathbf{8}$ (Figure $\mathrm{S} 1$ ) displayed two absorption maxima in the spectrum $\left[\lambda_{\max }\right.$ $\left(\mathrm{CH}_{3} \mathrm{NO}_{2}\right)\left(\varepsilon / \mathrm{M}^{-1} \mathrm{~cm}^{-1}\right)=462(1172)$ and $\left.642(612) \mathrm{nm}\right],{ }^{28}$ in good agreement with the electronic spectra reported for other diruthenium complexes containing $\mathrm{Ru}_{2}{ }^{6+}$ cores. ${ }^{29} \mathrm{In}$ contrast, the spectrum obtained for dicarba[2] ruthenocenophane 5 (Figure S2) displays no observable maxima over the same energy range.

The structure of $\mathbf{8}$ was confirmed by single crystal X-ray diffraction (Figure 5). Dimer $\mathbf{8}$ demonstrates unprecedented metal-metal bonding between $[n]$ metallocenophane units. Its structure represents one of the few known examples of a $\mathrm{Ru}{ }^{\mathrm{III}}-\mathrm{R} \mathrm{u}^{\mathrm{III}}$ bond not supported by a chelating ligand scaffold, ${ }^{30}$ although a crystallographically characterized osmocenium dimer dication has been previously reported. ${ }^{31}$ The $\mathrm{Ru}-\mathrm{Ru}$ bond length for $\mathbf{8}$ is 2.969(7) $\AA$, a significant increase from the average $\mathrm{Ru}-\mathrm{Ru}$ bond lengths reported for both diruthenium paddlewheel complexes containing supporting co-ligands and involving a number of oxidation states $(2.235-2.599 \AA),{ }^{33}$ and also in ligand-unsupported $\mathrm{Ru}-\mathrm{Ru}^{\mathrm{I}}$ complexes $(2.677-2.904 \AA) .{ }^{34}$ However, the bond is comparable in length to a ligand-supported [1.1]ruthenocenophane dication $[2.953(1) \AA] .{ }^{35}$ Interestingly, in the latter case, the close 
spatial proximity at which the metals were held together in the neutral, bimetallic precursor appears to facilitate $\mathrm{Ru} \mathrm{u}^{\mathrm{III}}-\mathrm{R} \mathrm{u}^{\mathrm{III}}$ bond formation. This type of effect cannot be operative in the formation of dimer $\mathbf{8}$, which supports the hypothesis that the tilted structure of dicarba[2]ruthenocenophane $\mathbf{5}$, and more exposed Ru center, significantly favours dimer formation. The $\alpha$ angles between the two sets of Cp rings are $48.18(18)^{\circ}$ and $41.83(10)^{\circ}$ for each metallocenophane unit respectively. ${ }^{36}$ The significant increase in this value from the dicarba[2]ruthenocenophane precursor $5\left[\alpha=29.6(5)^{\circ}\right],{ }^{11 a}$ presumably reflects the increased tilt required to accommodate $\mathrm{Ru}-\mathrm{Ru}$ bond formation.

a)

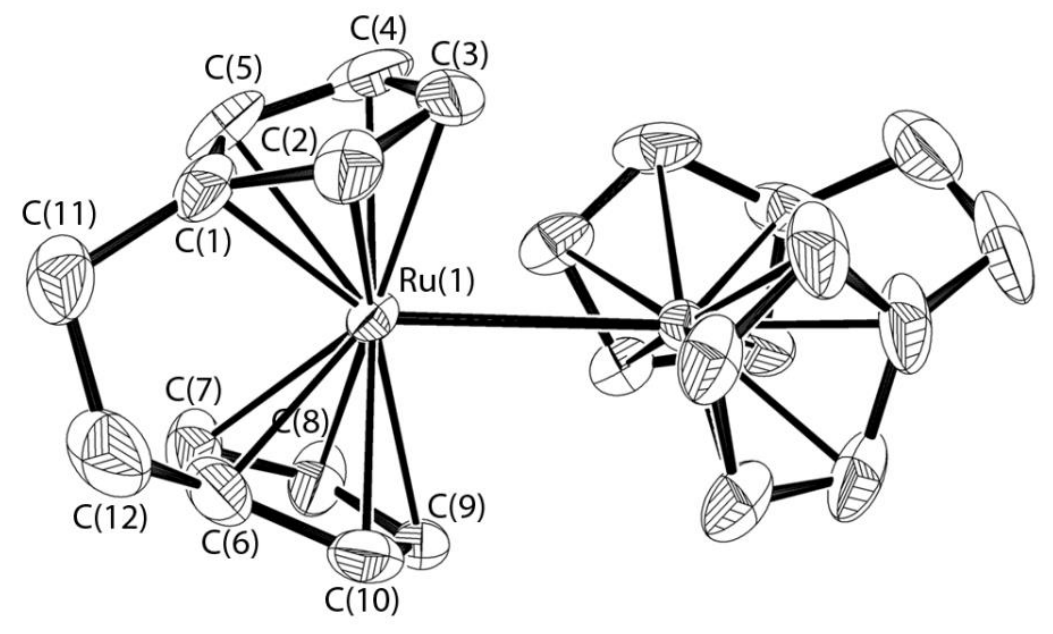

b)

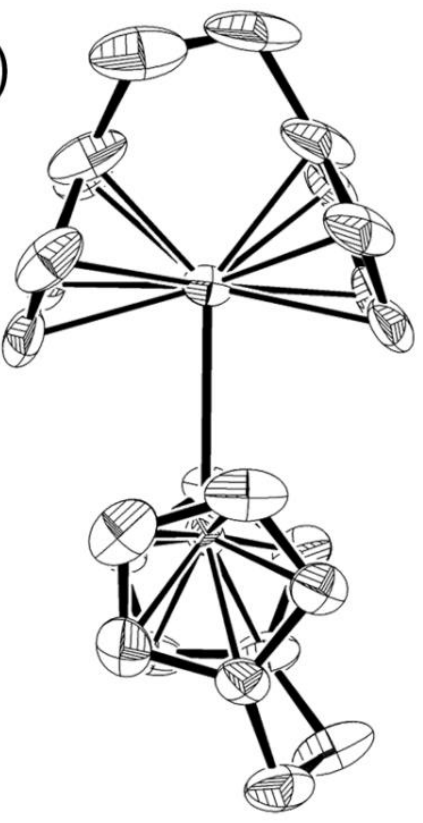

Figure 5. a) Solid-state structure of dication of 8. b) Different orientation of the solid-state structure of $\mathbf{8}$ to illustrate $90^{\circ}$ offset of metallocene units. ${ }^{32}$ Thermal ellipsoids shown at $50 \%$ probability level. Hydrogen atoms, solvent molecules, and counter ions have been omitted for clarity. Selected bond lengths ( $\AA$ ) and angles (deg): Ru1-Ru2 2.969(7), C1-C11 1.487(7), C6-C12 1.553(7), C11-C12 1.499(8): C2-C1-C11 125.2(3), C5-C1-C11 126.5(4), C1C11-C12 108.5(4), C11-C12-C6 112.7(4), C7-C6-C12 125.8(4), C10-C6-C12 126.8(3).

\section{2) Further Reactivity of Dicarba[2]ruthenocenophanium Dimer (8)}

a) Reaction with thiram, $\mathrm{Me}_{2} \mathrm{NC}(\mathrm{S}) \mathrm{S}-\mathrm{SC}(\mathrm{S}) \mathrm{NMe}_{2}$

We postulated that the $\mathrm{Ru}-\mathrm{Ru}$ bond in dimer $8(\mathrm{Ru}-\mathrm{Ru}=2.969 \AA)$ might undergo facile homolytic cleavage, potentially through addition of a stable radical species, and thus facilitate 
novel reactivity modes at the $\mathrm{Ru}$ metal center. Furthermore, the literature precedent for reactivity of disulfides with $\mathrm{Ru}$ complexes makes this class of compounds ideal candidates for reactions with dimer $\mathbf{8} .^{37}$ With compound $\mathbf{8}$ in hand, we therefore investigated its reactivity with dimethylcarbamothioylsulfanyl $\mathrm{N}, \mathrm{N}$-dimethylcarbamodithioate (thiram). A solution of thiram in $\mathrm{CD}_{3} \mathrm{NO}_{2}$ was added to a solution of $\mathbf{8}$ (also in $\mathrm{CD}_{3} \mathrm{NO}_{2}$ ) and stirred for $16 \mathrm{~h}$ affording a red-brown solution. ${ }^{1} \mathrm{H}$ NMR spectroscopic analysis in situ indicated complete consumption of the starting material. Upon work up, a yellow crystalline solid was obtained in poor isolated yield (7\%) which, when analyzed, was identified as the unusual and unexpected dimeric species 9 (Scheme 3). Cleavage of the $\mathrm{Ru}-\mathrm{Ru}$ bond in $\mathbf{8}$, with formation of a cyclobutane ring between $\mathrm{Cp}$ rings in an $\eta^{3}$ coordination mode, are involved in the formation of 9 . Although the product is formed in a very poor isolated yield, ${ }^{1} \mathrm{H}$ NMR spectroscopic analysis of the reaction solution indicated $33 \%$ conversion to $\mathbf{9}$, suggesting that the difficulty in crystallisation of this species dramatically reduces the amount of isolable product.

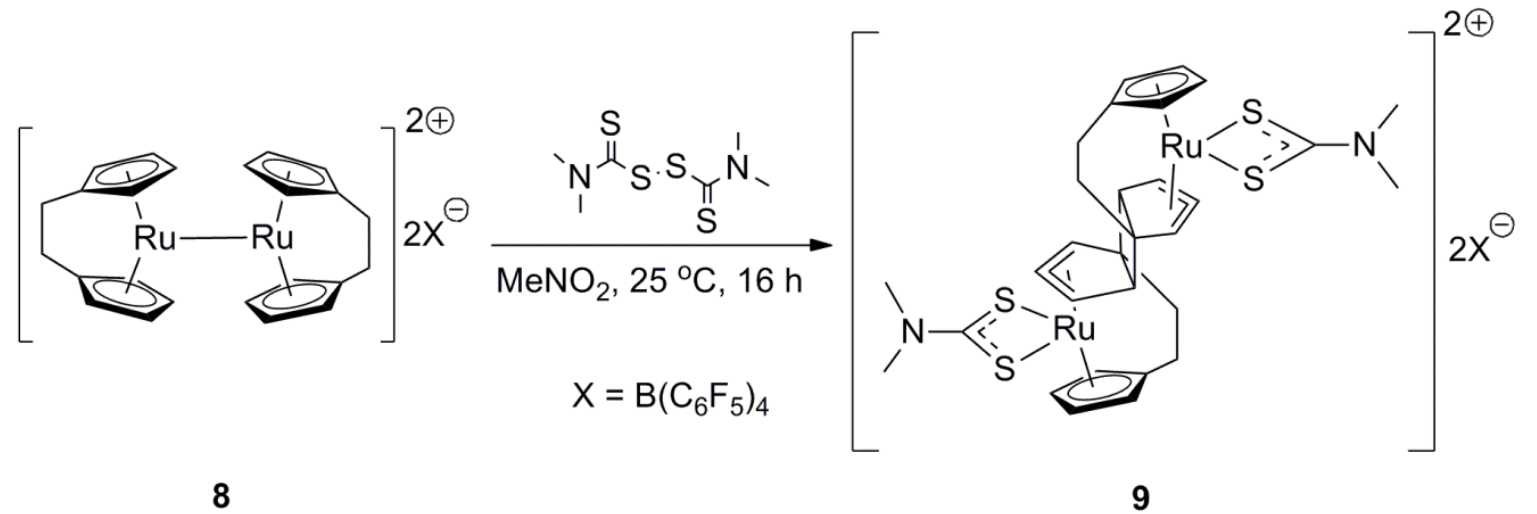

Scheme 3. Reaction of dimer 9 with thiram

Species 9 was characterized by ${ }^{1} \mathrm{H}$ NMR spectroscopic analysis (in $\mathrm{CD}_{3} \mathrm{NO}_{2}$ ) and displayed a doublet of doublets of doublets at $\delta=6.13$, assigned to the central allylic proton and two multiplets at $\delta=5.90-5.89$ and $5.77-5.75$ assigned to the other two allyl protons. Multiplets at $\delta=5.26-5.24$ and 4.47 were assigned to the $\alpha$ and $\beta$-protons of the $\eta^{5}-\mathrm{C}_{5} \mathrm{H}_{4}$ 
rings. A doublet of doublets at $\delta=4.99$ was assigned to the cyclobutane proton, and two overlapping singlets at $\delta=3.17$ assigned to the $\mathrm{CH}_{3}$ groups. Finally, two doublets of doublets of doublets at $\delta=2.71$ and 2.22 and two multiplets at $2.14-2.08$ and $2.01-1.95$ were assigned to the protons of the $\mathrm{C}_{2} \mathrm{H}_{4}$ bridge. ${ }^{13} \mathrm{C}\left\{{ }^{1} \mathrm{H}\right\}$ NMR spectroscopic and elemental analyses were conducted and also found to be consistent with the structural assignment. Definitive characterization of 9 was obtained through X-ray crystallographic analysis of a single yellow crystal, grown from a slowly cooled solution of $\mathrm{CH}_{3} \mathrm{NO}_{2}$ / diethyl ether (Figure $6)$.

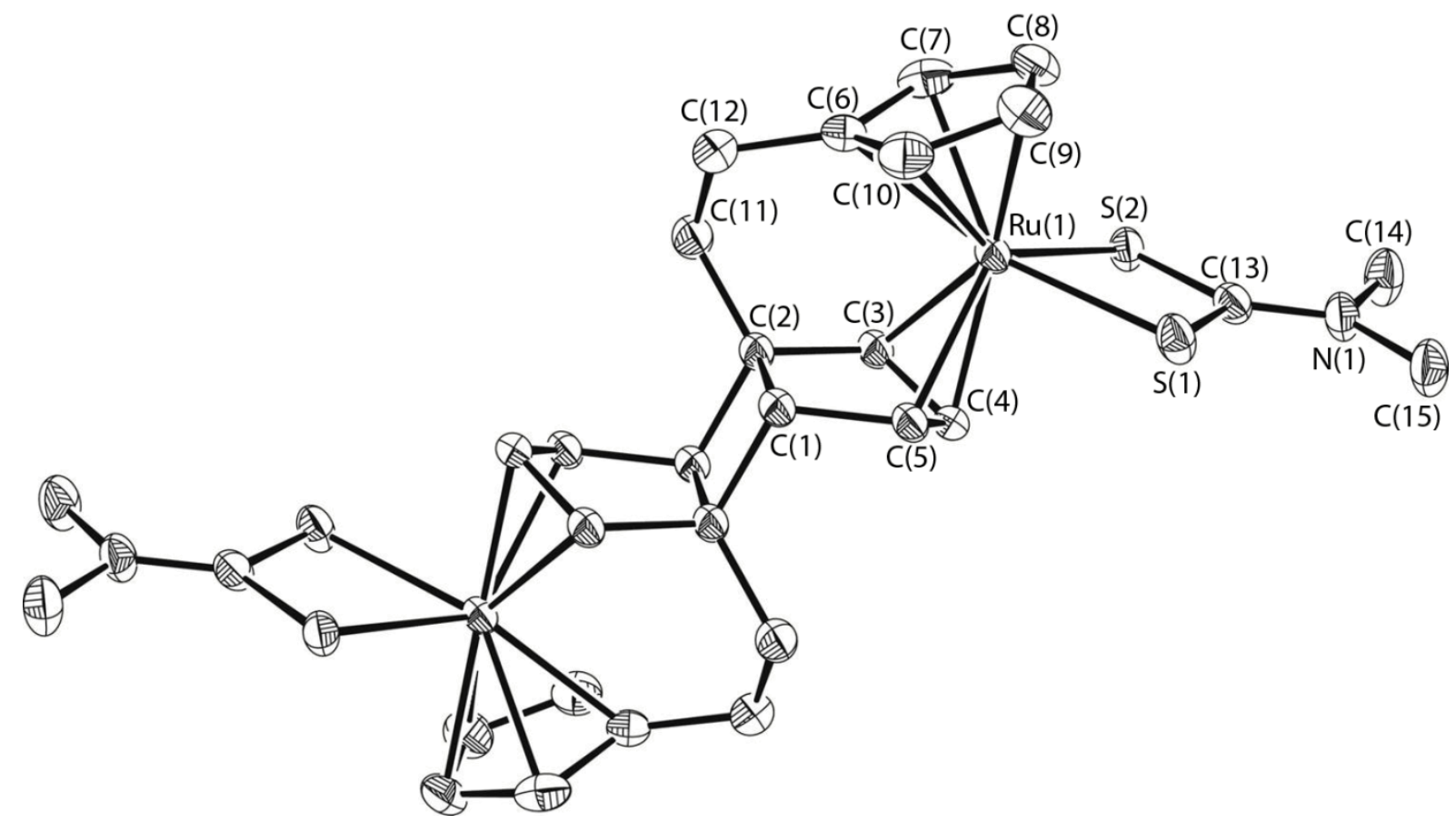

Figure 6: Solid state structure of the dication of 9. Thermal elipsoids at $50 \%$ probability level. Hydrogen atoms, solvent molecules and counter ions omitted for clarity. Selected bond lengths (A) and angles (deg): Ru1-S1 2.3892(7), Ru1-S2 2.3930(7), C6-C12 1.498(3), C1C11 1.534(3), C11-C12 1.535(4), C1-C2 1.569(3), C1-C2 1.593(3), C2-C3 1.511(3), C3C4 1.423(3), C4-C5 1.418(3): C1-C2-C1 90.07(16), C2-C1-C2 89.93(16), C6-C12-C11 114.4(2), C1-C11-C12 112.73(19), C3-C4-C5 104.6(2), C8-C9-C10 109.3(2).

Species 9 represents one of the few examples of a structurally characterized organometallic complex containing an $\eta^{3}$-coordinated cyclopentadienyl ligand. ${ }^{38}$ The shift from the $\eta^{5}$ to the $\eta^{3}$-allyl coordination mode results in folding of the internal $\mathrm{Cp}$ ring, a feature consistent with 
other organometallic complexes of this type. ${ }^{39}$ The degree of ring folding of the Cp ring in $\eta^{3}$ bound organometallic complexes is defined by $\omega$, the angle between the planes formed by the allylic and olefinic ring fragments (see Figure S3 for details), ${ }^{40}$ and is considerably greater in $9\left(\omega=30.44^{\circ}\right)$, than in other analogous complexes $\left(17.4-20.0^{\circ}\right),{ }^{38 a, 41}$ potentially reflecting the steric demands involved in formation of the cyclobutane ring.

The significant value for $\omega$ in $\mathbf{9}$ is reflected in the bond lengths between the $\mathrm{Ru}$ and the folded $\mathrm{Cp}$ ring carbons, in which the $\mathrm{Ru}-$ allyl bonds are considerably shorter $(\mathrm{Ru}-$ $\mathrm{C}(3) /(4) /(5)=2.117-2.240 \AA)$ than the $\mathrm{Ru}-\mathrm{C}(1)$ and $\mathrm{Ru}-\mathrm{C}(2)$ bond distances $(3.053-3.062$ $\AA$ A). The bond angles around the cyclobutane ring are as expected for such species (89.9 $90.1^{\circ}$ ). It is interesting to note the relative regiochemistry of the dicarba spacers, which lie in a 1,3 arrangement about the cyclobutane ring.

Due to the increased strength of M-Cp bonds relative to those for other $\pi$-conjugated ligands containing a $\mathrm{C}_{5}$ ring $($ e.g. Ind $=$ indenyl, Flu $=$ Fluorenyl $),{ }^{42}$ haptotropic $\eta^{5}$ to $\eta^{3}$ shifts of the $\mathrm{Cp}$ ligand are extremely rare. Despite being proposed as a mechanistic step in a range of organometallic reactions, ${ }^{43}$ this hapticity transformation has only actually been detected in solution, ${ }^{44}$ or implied from X-ray crystallographic analysis of the resulting $\eta^{3}-\mathrm{Cp}$ bound product, on a handful of occasions. ${ }^{41}$ In contrast, examples in the literature of $\eta^{5}-\eta^{3}$ haptotropic shifts in organometallic complexes containing $\mathrm{Cp}$ ligands fused to larger $\pi$ conjugated ring systems (e.g. Ind, Flu) are much more common, forming the basis of the "indenyl effect", whereby the kinetics of associative ligand substitution reactions are noticeably increased for complexes with these ligands, relative to their $\mathrm{Cp}$ analogues. ${ }^{43,45}$

We postulate a mechanism of formation for 9 (Scheme 4) in which homolytic cleavage of both $\mathrm{Ru}-\mathrm{Ru}$ and $\mathrm{S}-\mathrm{S}$ bonds facilitate the coordination of the dithiocarbamate with consequent oxidation of the $\mathrm{Ru}$ III metal center affording intermediate $\mathbf{1 0}$. Intramolecular coordination of the thiocarbamate group $(\mathrm{C}=\mathrm{S})$ might then induce the $\eta^{5}-\eta^{3}$ haptotropic shift of the $\mathrm{Cp}$ ring to 
maintain the 18-electron count of the metal to thereby afford transient intermediate $\mathbf{1 1}$. Formation of 9 could then be facilitated through a $2+2$ cycloaddition of the alkene moeity in the folded $\eta^{3}$-Cp ring of $\mathbf{1 1}$.

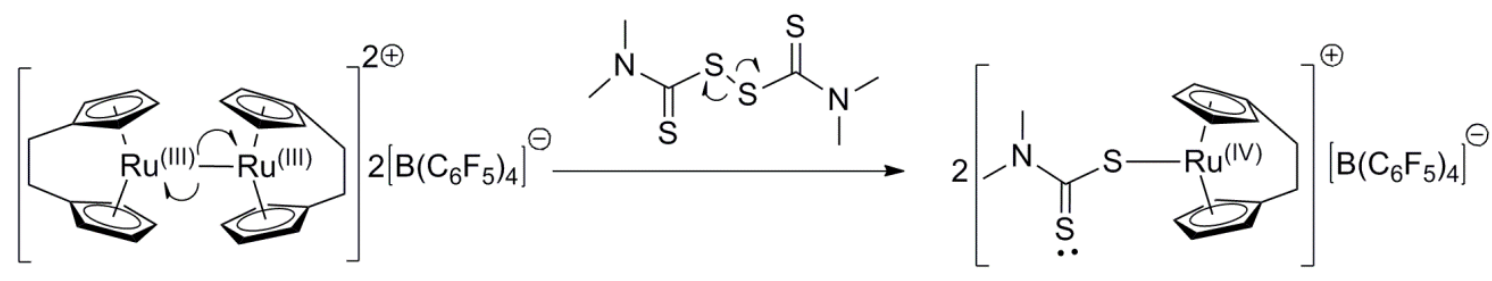

8

10

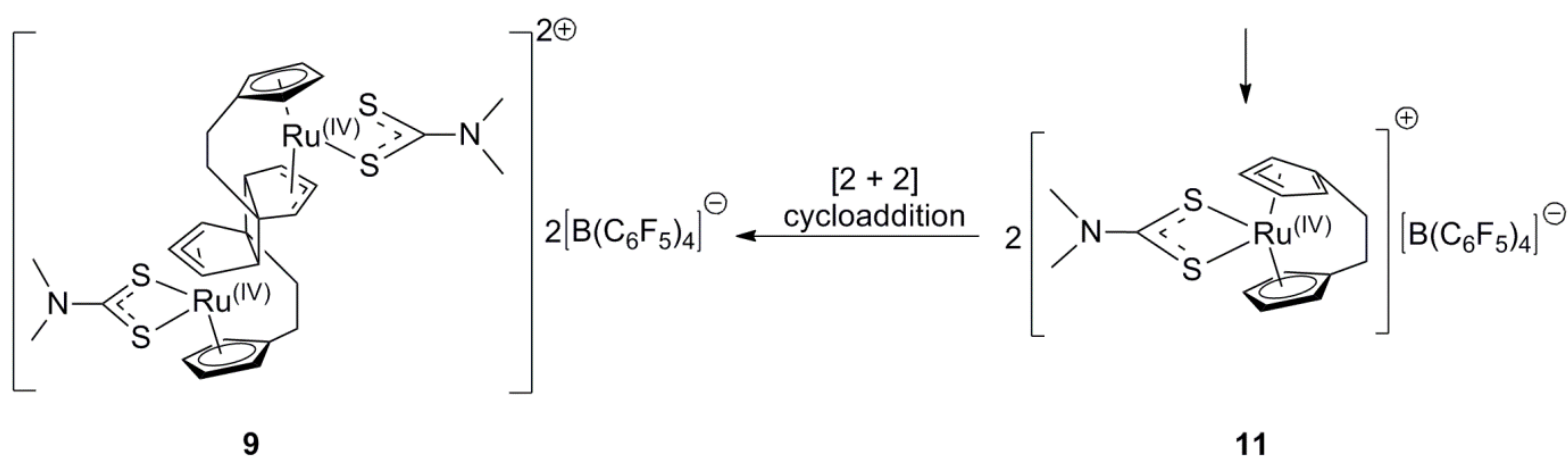

Scheme 4: Postulated Mechanism of Formation of Dimer 9

If the postualted mechanism is correct, this process would represent the first example of a $2+2$ cycloaddition between two $\mathrm{Cp}$ ligands in the $\eta^{3}$ coordination mode and is in contrast to other $\eta^{3}-\mathrm{Cp}$ organometallic complexes isolated, where the haptotropic shift occurs in the absence of further reactivity. ${ }^{46}$ The structure of $\mathbf{9}$, with the dicarba bridges coordinated in a 1,3 arrangement about the cyclobutane ring, is consistent with previously reported $2+2$ cycloadditions, where the head-to-tail regioisomer is favoured when employing an electron rich arene. ${ }^{47}$ Thus, the electron donating dicarba bridge in intermediate $\mathbf{1 1}$ may stabilize a formal positive charge in the alternative resonance form (Scheme S4), from which the 1,3 product is afforded. In addition, stereoselective dimerization (with formation of 9) is observed, from which the exo diastereomer is afforded, presumably to minimise steric interactions. However, given the moderate (33\%) conversion to 9, the potential formation of the different regioisomers and diastereoisomers of $\mathbf{9}$ cannot be excluded. ${ }^{48}$ 
Cycloaddition reactions involving metal-coordinated $\pi$-systems are relatively unexplored, with the majority of examples employing metal-coordinated allyl groups in cycloaddition reactions to form larger $\pi$-ring systems. ${ }^{49}$ Most significant to our observations, diruthenium species 12 undergoes a reaction with anthracene following bromide abstraction with AgOTf. In addition to the expected coordination product $\mathbf{1 3}$, tetramer $\mathbf{1 4}$ is also afforded through dimerization based on the internal $\mathrm{C}_{6}$-ring (Scheme 5). ${ }^{50}$ The authors also postulated that species $\mathbf{1 3}$ is, in fact, an intermediate in the formation of $\mathbf{1 4}$.

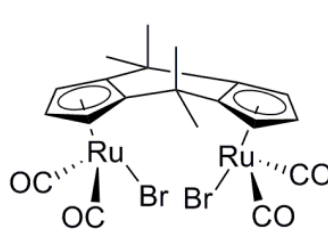

12

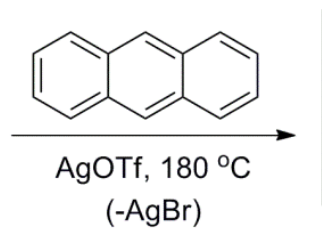

$(-\mathrm{AgBr})$

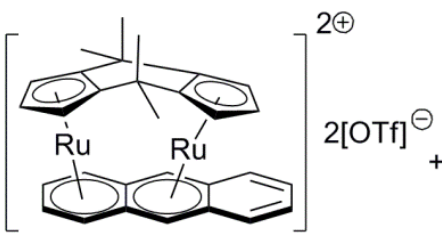

13

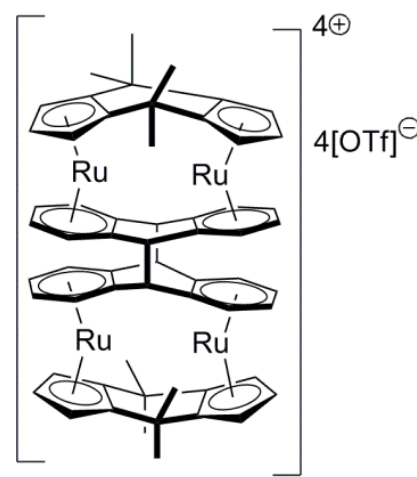

14

Scheme 5. Dimerization of anthracene upon coordination to dimer 12. ${ }^{50}$

\section{b) Reactivity of dimer 8 with PhE-EPh $(E=S$ or Se)}

To provide some support for the proposed mechanism of formation of unusual dimer 9 we attempted to synthesize analogs of the postulated reaction intermediate $\mathbf{1 0}$ (see Scheme 3) by using a source of organothio radicals that were incapable of chelation to the $\mathrm{Ru}$ centre. To this end, to a solution of dimer $\mathbf{8}$ (in $\mathrm{CD}_{3} \mathrm{NO}_{2}$ ) was added a solution of phenyl disulfide (also in $\mathrm{CD}_{3} \mathrm{NO}_{2}$ ). Over the 4 day reaction the dark green solution gradually turned dark brown, and in situ ${ }^{1} \mathrm{H}$ NMR spectroscopic analysis indicated complete conversion to a new product. Upon work up and recrystallization, species 15 was obtained in good yield (76\%) (Scheme $6)$. 


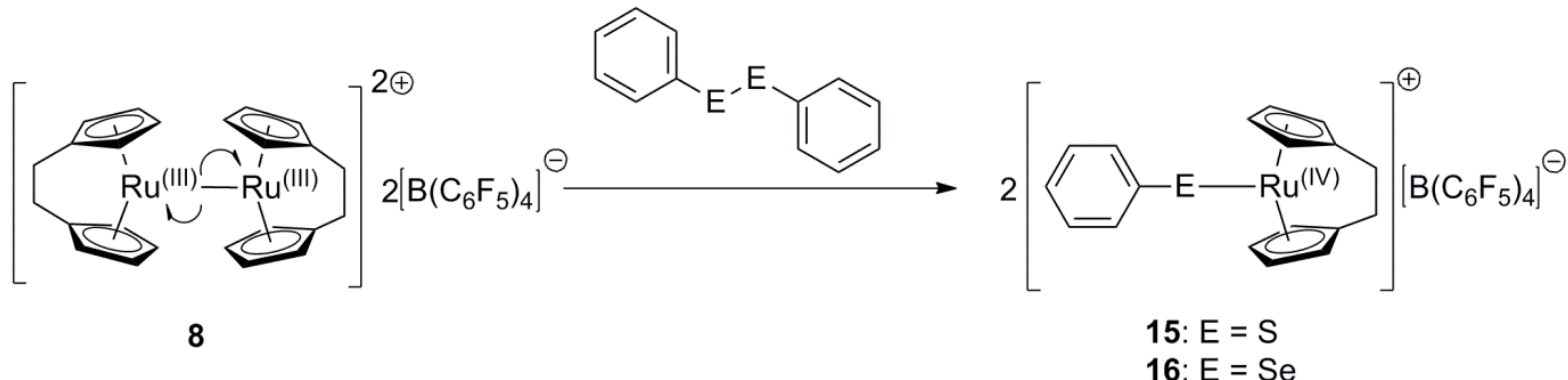

Scheme 6. Synthesis of $\mathbf{1 5}$ and $\mathbf{1 6 .}$

Species 15 was characterized by ${ }^{1} \mathrm{H}$ NMR, which displayed broad multiplets at $\delta=7.43-$ 7.41 and $7.17-7.14$, assigned to the phenyl protons, two multiplets at $6.69-6.68$ and 5.58 assigned to the $\mathrm{Cp}$ protons and a singlet at $3.31 \mathrm{ppm}$ assigned to the $\mathrm{CH}_{2}$ backbone. ${ }^{13} \mathrm{C}$ NMR spectroscopic and elemental analyses were also conducted and were found to be consistent with the assigned structure of $\mathbf{1 5}$. Further confirmation of the structure of $\mathbf{1 5}$ was obtained through X-ray crystallographic analysis of a single crystal formed through slow cooling a saturated solution of $\mathbf{1 5}$ in DCM/hexane (Figure 7).

a)

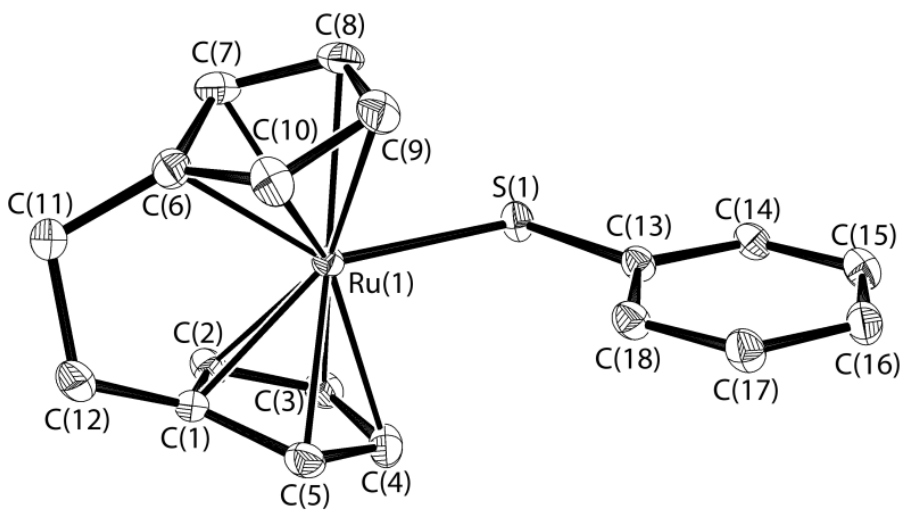

b)

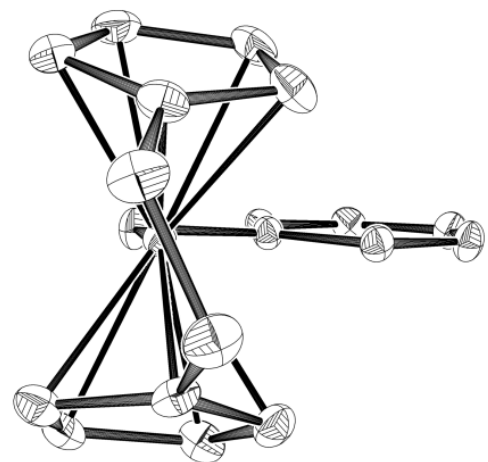

Figure 7: a) Solid state structure of cation of 15. b) Different orientation of the solid state structure of 15. Thermal elipsoids at $50 \%$ probability level. Hydrogen atoms and counter anions omitted for clarity. Selected bond lengths (A) and angles (deg): Ru1-S1 2.4107(12), C1-C11 1.507(7), C6-C12 1.517(7), C11-C12 1.529(8), S1-C13 1.763(5): Ru1-S1-C13 109.04(16), C1-C11-C12 108.9(5), C6-C12-C11 109.6(4).

The $\alpha$ angle for species $\mathbf{1 5}$ was found to be $38.77^{\circ}$, an increase from the angle in precursor $5\left[\alpha=29.6(5)^{\circ}\right]$, but a decrease compared to that observed in dimer $8\left[\alpha=48.18(18)^{\circ}-\right.$ $\left.48.83(10)^{\circ}\right]$, suggesting that the steric strain associated with the formation of the $\mathrm{Ru}-\mathrm{Ru}$ bond 
in $\mathbf{8}$ increases the tilt angle. The $\mathrm{Ru}-\mathrm{S}$ bond length $(2.4107 \AA)$ in $\mathbf{1 5}$ is similar to that in related species,${ }^{51}$ and the phenyl ring is positioned $\mathrm{ca} .90^{\circ}$ with respect to the dicarba-bridge $\mathrm{C}-\mathrm{C}$ bond, presumably to minimize steric repulsion with the $\mathrm{Cp}$ rings.

A similar reactivity pathway to that affording $\mathbf{1 5}$ was also observed upon treatment of $\mathbf{8}$ with phenyl diselenide. The analogous species $\mathbf{1 6}$ (Scheme 6) was isolated as a red/brown crystalline solid in a moderate yield $(53 \%)$. The product was analyzed by ${ }^{1} \mathrm{H}$ and ${ }^{13} \mathrm{C}$ NMR spectroscopic and elemental analyses, which were consistent with the assigned structure. Crystals suitable for X-ray analysis were obtained through slow cooling a solution of $\mathrm{CH}_{2} \mathrm{Cl}_{2}$ /hexane (Figure 8). The alpha angle in $\mathbf{1 6}$ was shown to be $40.1^{\circ}$, a slight increase compared to that in $\mathbf{1 5}$ and the Ru-Se bond length of 2.5751(5) $\AA$ was found to be similar to other species containing a Ru-Se bond..$^{37 \mathrm{c}}$

a)

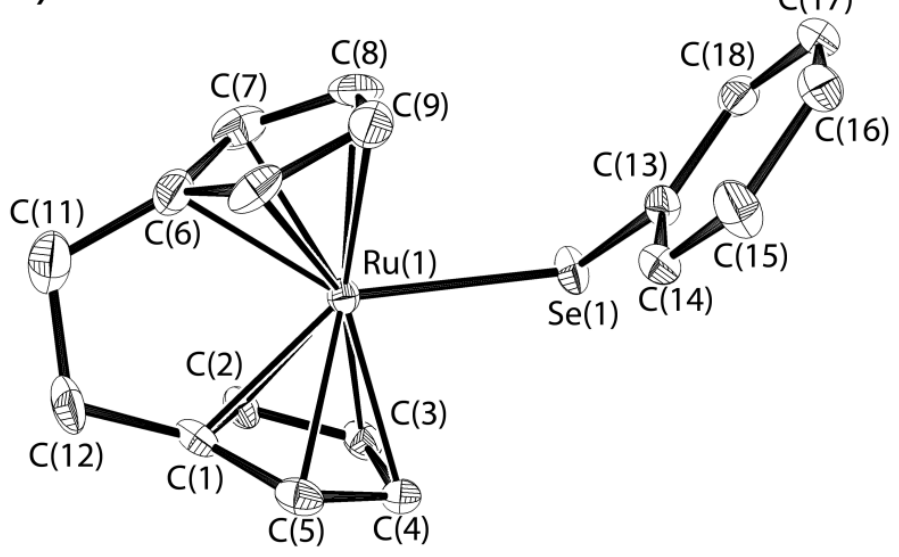

b)

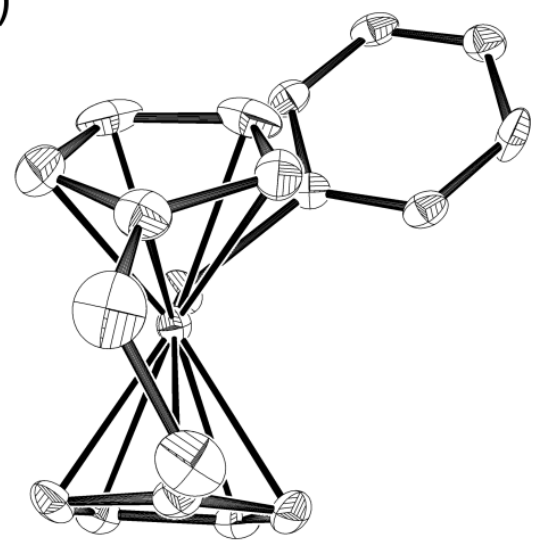

Figure 8: a) Solid state structure of cation of 16. b) Different orientation of the solid state structure of 16. Thermal elipsoids at $50 \%$ probability level. Hydrogen atoms and counter anions omitted for clarity. Selected bond lengths $(\AA)$ and angles (deg): Ru1-Se1 2.5751(5), C1-C11 1.501(6), C6-C12 1.505(6), C11-C12 1.516(7), Se1-C13 1.915(4): Ru1-Se1-C13 105.07(11), C1-C11-C12 108.8(3), C6-C12-C11 109.7(4).

Next, our attention turned to whether the unusual $\eta^{5}$ to $\eta^{3}$ slippage of the Cp ligand could be induced in intermediate $\mathbf{1 5}$, a process we propose to be achieved by chelation in the case of intermediate $\mathbf{1 0}$ (Scheme 4). Typically, ring-slippages of this nature are induced through the addition of a two electron donor, or by reduction of the metal, in both cases forcing the 
Cp ligand into the lower coordination mode to preserve the 18 -electron count at the metal center. ${ }^{38 \mathrm{~b}}$ Several attempts to add two electron donors, including $\mathrm{CO}$ and $\mathrm{MeCN}$ which are known to induce $\eta^{5}-\eta^{3}$ haptotropic transformations in organometallics complexes containing coordinated $\pi-\mathrm{C}_{5}$ ring systems, ${ }^{38 \mathrm{a}, 41,44}$ resulted in no observable reaction with $\mathbf{1 5}$. However, reaction of 15 with excess $\mathrm{PMe}_{3}$ afforded a single new phosphorus-containing product, as observed by in situ ${ }^{31} \mathrm{P}$ NMR spectroscopy $[\delta=24.0 \mathrm{ppm}]$. Although, ${ }^{1} \mathrm{H}$ NMR spectroscopic analysis indicated the formation of a new product(s), it also suggested that a $\eta^{5}-\eta^{3}$ haptotropic transformation had not taken place. ${ }^{52}$

The reaction of 15 with N-heterocyclic carbene 1,3-bis(2,6-diisopropylphenyl)imidazol-2ylidene (IPr) resulted in further reactivity as demonstrated by in situ ${ }^{1} \mathrm{H}$ NMR spectoscopic analysis. The spectrum, similar to that obtained for $\mathbf{9}$, displayed multiple signals assigned to $\mathrm{Cp}$ protons, and is consistent with a species of lower symmetry, formed after a potential hapticity shift and dimerization of the Cp ligand (see S9 for details). Unfortunately, attempts to grow single crystals for X-ray crystallographic analysis from the products of both this reaction, and the reaction of $\mathbf{1 5}$ with $\mathrm{PMe}_{3}$, were unsuccesful.

Species $\mathbf{1 5}$ and $\mathbf{1 6}$ are analogues to the reaction intermediate 10, and their isolation provides evidence to support the postulated mechanism of formation for $\mathbf{9}$ (Scheme 4). However, no evidence to support the presence of intermediate $\mathbf{1 1}$ in the reaction pathway could be obtained. The inability to isolate a product containing an $\eta^{3}$-coordinated $\mathrm{Cp}$ ring, from the addition of 2 electron donor to $\mathbf{1 5}$, means that the possibility that 9 is formed through an alternative mechanism must also be considered.

\section{3) Electrochemical Properties of Tricarba[3]ruthenocenophane 6 and Dimethylruthenocene 7}

The contrasting redox behaviour observed for dicarba[2]ruthenocenophane $\mathbf{5}$ relative to that reported for unstrained ruthenocene, prompted further investigations into the effect of tilt on 
the redox properties of ruthenocene-containing species. To this end, electrochemical studies of less tilted tricarba[3]ruthenocenophane $6\left(\alpha=14.8^{\circ}\right)$ and unstrained dimethylruthenocene $7\left(\alpha=0^{\circ}\right)$ were also conducted (Figure 3). The latter species, bearing similar Cp ring substituents to $\mathbf{5}$, can be regarded as an untilted, acyclic analog to $\mathbf{5}$ and $\mathbf{6}$, allowing the effects of tilt alone on the redox properties to be assessed.

\section{a) Electrochemical Studies of Tricarba[3]ruthenocenophane 6 and the Synthesis and Characterization of Tricarba[3]ruthenocenophanium Dimer 17}

Species 6, which has previously been synthesized through reduction of a [3]ruthecenophan-1-one precursor, ${ }^{53}$ and crystallographically characterized, ${ }^{54}$ was prepared in this instance through a similar procedure to that employed for $5 .{ }^{11 \mathrm{a}}$ Thus, $\mathrm{RuCl}_{2}(\mathrm{DMSO})_{4}$ and $\mathrm{Li}_{2}\left[\left(\eta^{5}-\mathrm{C}_{5} \mathrm{H}_{4}\right)_{2}\left(\mathrm{CH}_{2}\right)_{3}\right]$ were combined in THF at $-78{ }^{\circ} \mathrm{C}$. Upon work up, species 6 was afforded as a pale yellow crystalline solid in low yield (22\%). ${ }^{1} \mathrm{H}$ NMR spectroscopic analysis was conducted and found to be consistent with the data reported previously for this species..$^{53}$

With compound $\mathbf{6}$ in hand, we investigated its electrochemical properties. Similar to 5, CV scans of $\mathbf{6}\left(v=0.2 \mathrm{~V} \mathrm{~s}^{-1}, \mathrm{CH}_{2} \mathrm{Cl}_{2}\right)$ showed that it undergoes a one electron oxidation to afford a single electroactive product (Figure 9) although at a higher potential (by $c a .280 \mathrm{mV}$ ) than for [2]ruthenocenophane 5. The oxidation was found to be an electrochemically irreversible process under standard electrochemical conditions ( $1 \mathrm{mM}$ analyte, $\left.v=0.2 \mathrm{~V} \mathrm{~s}^{-1}\right)$, and dimerization of the monocation and formation of the dicationic dimer $\mathbf{1 7}$ occurs rapidly. However, in contrast to $\mathbf{5}$, which displays temperature and concentration independent electrochemical properties, an electrochemically reversible oxidation of species $6\left(\mathrm{E}_{1 / 2}=0.28\right.$ $\mathrm{V} v s . \mathrm{FcH})$ to monocation $6^{+}$was observed at higher scan rates $\left(v=5 \mathrm{~V} \mathrm{~s}^{-1}\right)$. 


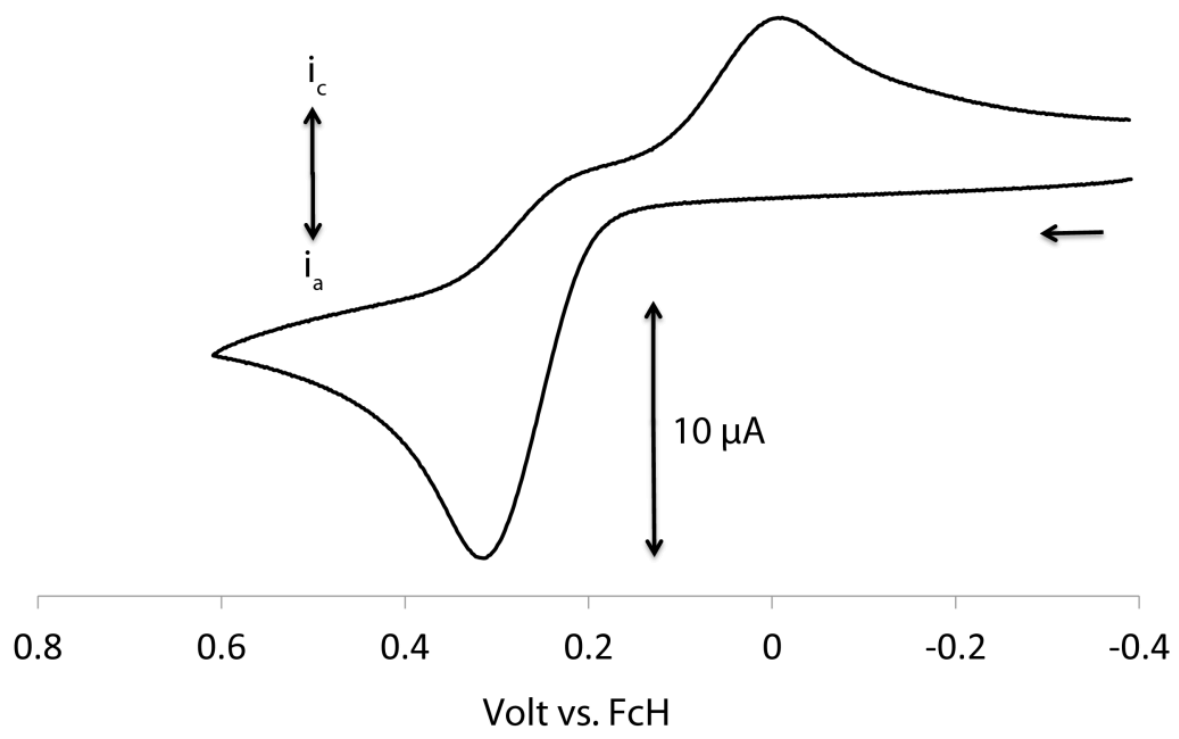

Figure 9: Cyclic voltammogram of a $\mathrm{CH}_{2} \mathrm{Cl}_{2}$ solution of 6 (ca. $1 \mathrm{mM}$ analyte, $0.05 \mathrm{M}$ $\left[n \mathrm{Bu}_{4} \mathrm{~N}\right]\left[\mathrm{B}\left(\mathrm{C}_{6} \mathrm{~F}_{5}\right)_{4}\right]$, scan rate $\left.=0.2 \mathrm{~V} \mathrm{~s}^{-1},-20{ }^{\circ} \mathrm{C}\right)$.

Interestingly, cation $\mathbf{6}^{+}$appears only stable at reduced temperatures $\left(-20{ }^{\circ} \mathrm{C}\right)$ as, in contrast to $\mathbf{5}^{+}$, more complex electrochemical behaviour is observed when cyclic voltammetric analysis is conducted at ambient temperatures. Thus, further reactivity of monocation $\mathbf{6}^{+}$and the formation of unidentified byproducts in addition to $\mathbf{1 7}$ occurs. ${ }^{55}$ These observations, in concert with the reported electrochemically reversible behavior of cation $\mathbf{6}^{+}$at fast scan rates, are consistent with a rate of dimerization for this species that is slower than for $\mathbf{6}^{+}$, and a sufficiently long lifetime in solution to facilitate reactivity pathways other than dimerization.

Bulk chemical oxidation of $\mathbf{6}$ was conducted in order to isolate dimer 17. The contrasting oxidation potentials for the two species was considered when selecting a suitable oxidant, as for species $6\left(\mathrm{E}_{1 / 2}=0.28 \mathrm{~V} v s . \mathrm{FcH}, \mathrm{E}_{\mathrm{pa}}=0.34 \mathrm{~V} v s . \mathrm{FcH}\right)$, which oxidizes at a higher potential than $5\left(\mathrm{E}_{\mathrm{pa}}=0.05 \mathrm{~V} v s . \mathrm{FcH}\right)$, acetylferrocenium tetra(pentafluorophenyl)borate $(0.27 \mathrm{~V} v s . \mathrm{FcH})$, employed in the formation of $\mathbf{8}$, is not sufficiently oxidizing. We therefore turned our attention to tris(4-bromophenyl)aminium tetra(pentafluorophenyl)borate $\left[\mathrm{N}\left(\mathrm{C}_{6} \mathrm{H}_{4} \mathrm{Br}\right)_{3}\right]\left[\mathrm{B}\left(\mathrm{C}_{6} \mathrm{~F}_{5}\right)_{4}\right],(0.7 \mathrm{~V}$ vs. $\mathrm{FcH}) .{ }^{21}$ Upon addition of a stoichiometric amount of $\left[\mathrm{N}\left(\mathrm{C}_{6} \mathrm{H}_{4} \mathrm{Br}\right)_{3}\right]\left[\mathrm{B}\left(\mathrm{C}_{6} \mathrm{~F}_{5}\right)_{4}\right]$ to a solution of $6\left(\mathrm{CH}_{2} \mathrm{Cl}_{2},-20{ }^{\circ} \mathrm{C}\right)$, a brown precipitate was afforded (yield $=39 \%) .{ }^{56}{ }^{1} \mathrm{H}$ NMR spectroscopic analysis revealed downfield signals for the protons 
environments in species $\mathbf{1 7}$ relative to neutral precursor $\mathbf{6}$, consistent with the observations made for dimer 8. Thus, two triplets at $\delta=5.35$ and 5.15 were assigned to the $\alpha$ - and $\beta$-Cp protons, a multiplet at $2.13-2.12$ assigned to the protons on carbons 1 and 3 of the tricarba bridge, and a multiplet at $1.97-1.92 \mathrm{ppm}$ assigned to the protons of the central bridging carbon (Figure S5). ${ }^{13} \mathrm{C}$ NMR spectroscopic and elemental analyses were also conducted and found to be consistent with the assigned structure (see SI for details). UV-vis spectroscopic analysis of 17 (Figure S6) displayed two adsorptions $\left[\lambda_{\max }\left(\mathrm{CH}_{3} \mathrm{NO}_{2}\right)\left(\varepsilon / \mathrm{M}^{-1} \mathrm{~cm}^{-1}\right)=400\right.$ (7480) and $608(1500) \mathrm{nm}]$ similar to those for both dimer 8 and the other diruthenium

species containing $\mathrm{Ru}_{2}{ }^{6+}$ cores. ${ }^{29}$ Finally, the observation that bulk chemical reduction of $\mathbf{1 7}$ (at $-20{ }^{\circ} \mathrm{C}$ ) reaffords species 6 (see SI for details), consistent with the observations for 8 , strongly supports the conclusion that dimer $\mathbf{1 7}$ is formed upon oxidation. Unfortunately attempts to grow crystals of $\mathbf{1 7}$ suitable for X-ray crystallographic analysis were unsuccessful. $^{57}$

\section{b) Electrochemical Studies of Dimethylruthenocene 7}

Next our attention turned to the investigation of the electrochemical properties of dimethylruthenocene 7 as a direct, unstrained analog of $\mathbf{5}$. Cyclic voltammetric studies $(v=$ $0.2 \mathrm{~V} \mathrm{~s}^{-1}$ ) of this species displayed contrasting electrochemical behaviour to that observed for ruthenocenophanes 5 and 6 (Figure 10). 


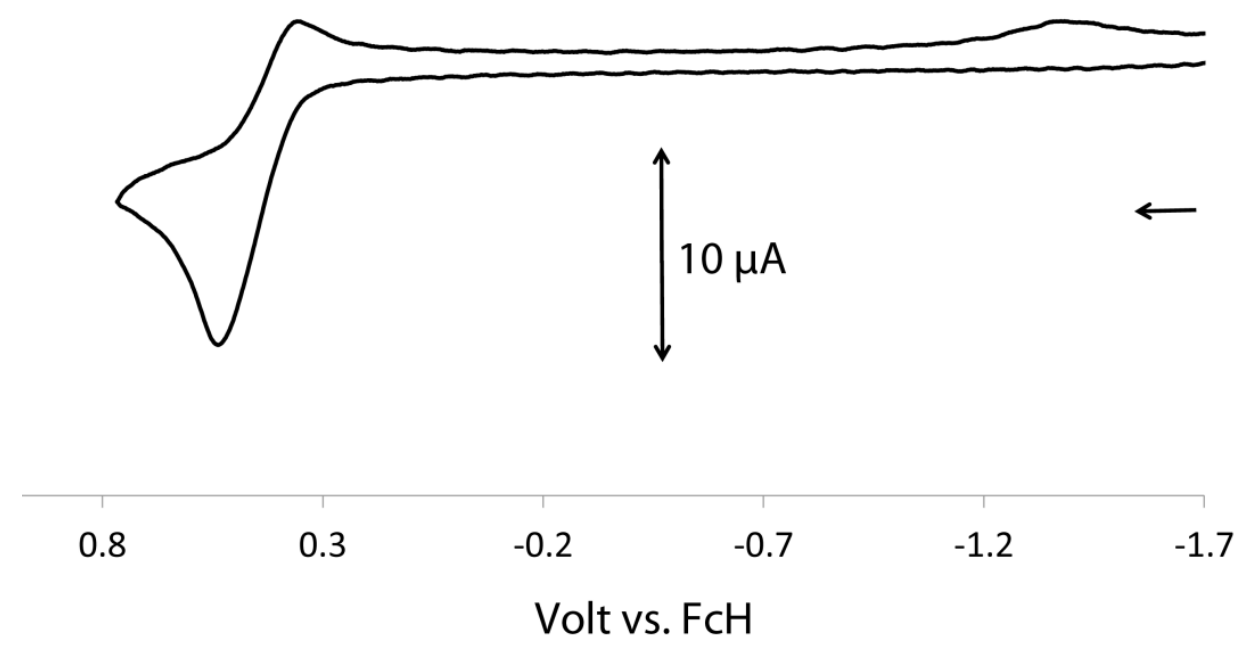

Figure 10: Cyclic voltammogram of a $\mathrm{CH}_{2} \mathrm{Cl}_{2}$ solution of 7 ( $\mathrm{ca} .1 \mathrm{mM}$ analyte, $0.05 \mathrm{M}$ $\left[n \mathrm{Bu}_{4} \mathrm{~N}\right]\left[\mathrm{B}\left(\mathrm{C}_{6} \mathrm{~F}_{5}\right)_{4}\right]$, scan rate $\left.=0.5 \mathrm{~V} \mathrm{~s}^{-1},-20^{\circ} \mathrm{C}\right)$.

Similar to the case for ruthenocene, ${ }^{24 d}$ the cyclic voltammogram obtained for $\mathbf{7}$ had a quasi-Nerstian shape $\left(\mathrm{E}_{1 / 2}=0.44 \mathrm{~V} v s . \mathrm{FcH}\right)$ and a new reduction peak appeared at a lower potential than expected for the reduction of cation $7^{+}$. However, the position of the peak is significantly more negative $\left(\mathrm{E}_{\mathrm{pc}}=-1.37 \mathrm{~V}\right.$ vs. $\left.\mathrm{FcH}\right)$ than expected for the reduction of a dicationic dimer. Furthermore, the peak is more prominent at slower scan rates, which is inconsistent with both the formation of a dimer and the electrochemical properties of ruthenocene. In situ ${ }^{1} \mathrm{H}$ NMR spectroscopic analysis did not allow for identification of the product. $^{58}$

To investigate further, chemical oxidation of 7 was conducted utilizing the same aminium oxidant as employed in the formation of dimer 17. To this end, a stoichiometric amount of $\left[\mathrm{N}\left(\mathrm{C}_{6} \mathrm{H}_{4} \mathrm{Br}\right)_{3}\right]\left[\mathrm{B}\left(\mathrm{C}_{6} \mathrm{~F}_{5}\right)_{4}\right]$ was added to a solution of $7\left(\mathrm{CH}_{2} \mathrm{Cl}_{2}, 25^{\circ} \mathrm{C}\right)$. No precipitate was formed and the dark blue solution gradually turned black over the course of the $16 \mathrm{~h}$ reaction. Upon work-up a black crystalline product was afforded in near quantitative yield (96 \%) and was identified, upon analysis, as $\left[\mathrm{Ru}\left(\eta^{5}-\mathrm{C}_{5} \mathrm{H}_{4} \mathrm{Me}\right)_{2} \mathrm{Br}\right]\left[\mathrm{B}\left(\mathrm{C}_{6} \mathrm{~F}_{5}\right)_{4}\right](\mathbf{1 8})$ (Scheme 7). 


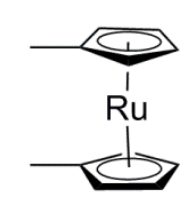

7

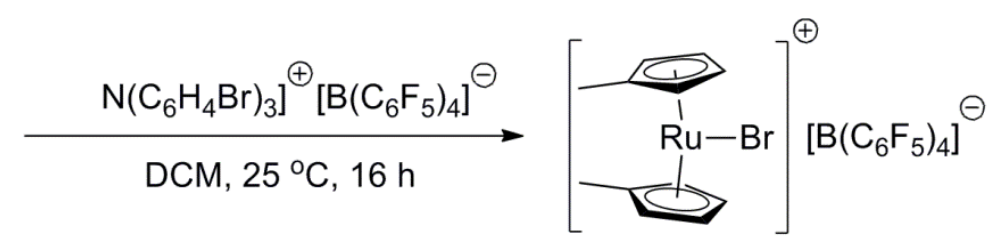

18

Scheme 7. Oxidation of 7 with $\left[\mathrm{N}\left(\mathrm{C}_{6} \mathrm{H}_{4} \mathrm{Br}\right)_{3}\right]\left[\mathrm{B}\left(\mathrm{C}_{6} \mathrm{~F}_{5}\right)_{4}\right]$

The product was fully characterized by NMR spectroscopy, which displayed downfield resonances relative to those for 7 . Thus, two triplets at $\delta=5.73$ and 5.63 were assigned to the $\mathrm{Cp}$ protons and a singlet at $2.35 \mathrm{ppm}$ was assigned to the methyl groups. Elemental and ${ }^{13} \mathrm{C}$ NMR spectroscopic analyses were also conducted which were consistent with the assigned structure. Full structural confirmation of the product was obtained through X-ray crystallographic analysis of a single crystal of $\mathbf{1 8}$, grown through slow cooling a $\mathrm{CH}_{2} \mathrm{Cl}_{2}$ / hexane solution (Figure 11).

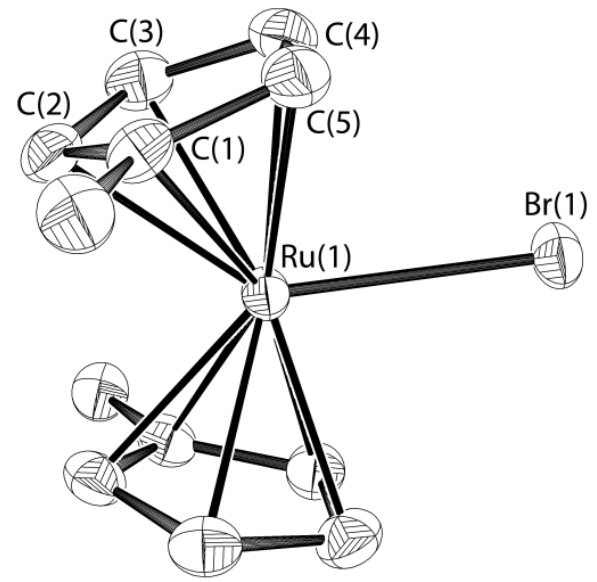

Figure 11: Solid state structure of cation of 18. Thermal elipsoids at $50 \%$ probability level. Hydrogen atoms and counter anion omitted for clarity. Selected bond lengths $(\AA)$ and angles (deg): Ru1-Br1 2.5469(6), C1-C6 1.472(5), Ru1-C5 2.198(3), Ru1-C2 2.200(3), Ru1-C3 2.254(3), Ru1-C4 2.221(3), Ru1-C1 2.244(3): Ru1-C1-C6 127.0(2).

The two $\mathrm{Cp}$ rings in $\mathbf{1 8}$ are tilted away from the $\mathrm{Ru}-\mathrm{Br}$ bond and the methyl substituents are positioned in a pseudo trans configuration, presumably to reduce steric interactions. The $\mathrm{Cp}$ rings adopt an almost eclipsed arrangement. We postulate that upon oxidation, strongly electrophilic cation $7^{+}$is prone to undergo reactions that allow the reattainment of an 18 electron configuration, and that bromide abstraction from the byproduct $\left[\mathrm{N}\left(\mathrm{C}_{6} \mathrm{H}_{4} \mathrm{Br}\right)_{3}\right]$, is 
apparently the preferred reaction pathway, rather than dimerization. Further attempts to oxidize 7 with other oxidants such as $\operatorname{Ag}\left[\mathrm{B}\left(\mathrm{C}_{6} \mathrm{~F}_{5}\right)_{4}\right]$ also failed to result in the successful isolation of either the dimer dication or the new oxidation product formed from the electrochemical studies. ${ }^{59}$

\section{4) Computational Investigations into the Effect of Ring-Tilt on Oxidation Potential and Dimerization Propensity}

To provide further insight into the effect of $\mathrm{Cp}$ ring tilt on the propensity for dimerization of oxidized ruthenocene containing species, computational studies were conducted using the B3LYP density functional method, including dispersion corrections (see SI for details). The geometry optimized structure of $\mathbf{8}$ was in good agreement with the structure determined from X-ray crystallography (See S25). Reported energies are based on single-point calculations with a larger basis set and a continuum solvent model.

The singly occupied molecular orbitals (SOMOs) for the hypothetical monocarba[1] ruthenocenophanium cation $\mathbf{1 9}^{+}$, dicarba[2]ruthenocenophanium $\mathbf{5}^{+}$, the tricarba[2]ruthenocenophanium cation $\mathbf{6}^{+}$and the parent ruthenocenium cation $\left(\mathrm{RuCp}_{2}{ }^{+}\right)$ differ substantially (Figure 12). Crucially, the SOMO orbitals for $\mathbf{1 9}^{+}, \mathbf{5}^{+}$and $\mathbf{6}^{+}$, which have significant $\mathrm{d}$ character, protrude from the exposed $\mathrm{Ru}$ metal center, facilitating $\mathrm{Ru}-\mathrm{Ru}$ bond formation. Calculations also suggest that the standard free energy (at $298 \mathrm{~K}$ ) for dissociation of the dimeric structure increases with higher tilt angle $\alpha$ (Figure 12). ${ }^{60}$ Experimentally, the equilibrium constant for the reversible dimerization of $\mathrm{RuCp}_{2}{ }^{+}$in $\mathrm{CH}_{2} \mathrm{Cl}_{2}$ was estimated to be $9 \times 10^{4} \mathrm{M}^{-1}$ at $243 \mathrm{~K},{ }^{24 \mathrm{~d}}$ corresponding to a dissociation free energy of $5.5 \mathrm{kcal} \mathrm{mol}^{-1}$ at that temperature. Given the different solvent, and the many remaining sources of errors in the computational method, this is in fair agreement with the calculated value of $7.3 \mathrm{kcal} \mathrm{mol}^{-1}$ at 
$298 \mathbf{K}$, and the greater calculated free energy of dissociation for the dimer of $\mathbf{5}^{+}$is consistent with its irreversible formation.

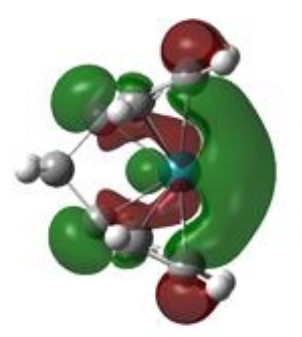

Species

$\alpha$

Dissociation energy
$/ \mathrm{kcal}^{\mathrm{mol}^{-1}}$

Oxidation potential

$\left(\mathrm{E}_{1 / 2}\right) / \mathrm{V}$ vs. $\mathbf{F c H}^{\mathrm{b}}$

Oxidation potential

/ V vs. $\mathbf{F c H}^{\mathrm{c}}$
20.79

$-0.09$

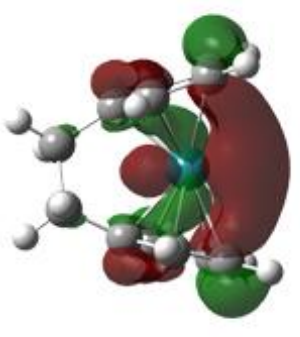

$\mathbf{5}^{+}$

29.6(5)

18.81

$0.00^{\mathrm{d}}$

0.25

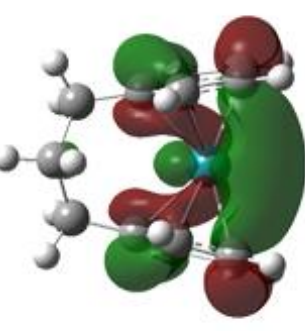

$6^{+}$

$14.8(2)$

13.13

0.28

0.50
$+$

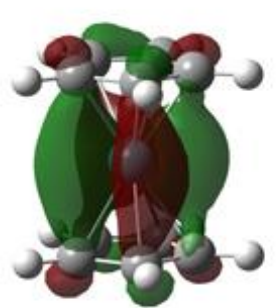

ruthenocenium

0

7.30

0.79

Figure 12. SOMO representations, structural and electrochemical data for $\mathbf{1 9}^{+}, \mathbf{5}^{+}, \mathbf{6}^{+}$and ruthenocenium. Isodensity value $=0.03$ (See supplementary information for computational details). ${ }^{a}$ Angle taken from calculated optimized structure. ${ }^{b}$ From electrochemical measurements. ${ }^{\mathrm{c}}$ From calculations. ${ }^{\mathrm{d}} \mathrm{E}_{1 / 2}$ estimated from experimental $\mathrm{E}_{\mathrm{pa}}$ value (see section 1).

Calculations correctly predict that the one-electron oxidation of $6(0.50 \mathrm{~V}$ vs. FcH $), 5$ $(0.25 \mathrm{~V}$ vs. $\mathrm{FcH})$, and hypothetical $19(-0.09 \mathrm{~V}$ vs. $\mathrm{FcH})$ will be more facile than that of $\mathrm{RuCp}_{2}(0.79 \mathrm{~V} v s . \mathrm{FcH})$. In addition, the difference in oxidation potentials between the $\mathrm{Ru}$ and $\mathrm{Fe}$ congeners decreases with increasing tilt angle $\alpha$, and thus are larger in the metallocenes $(\Delta \mathrm{E}$ calc. $=0.79 \mathrm{~V})$ than for the tricarba $(\Delta \mathrm{E}$ calc. $=0.59 \mathrm{~V})$, dicarba $(\Delta \mathrm{E}$ calc. $=0.18 \mathrm{~V})$ and hypothetical monocarba $(\Delta \mathrm{E}$ calc. $=-0.6 \mathrm{~V})$ metallocenophanes $($ See Table S2). ${ }^{61}$

The $\mathrm{E}_{1 / 2}$ value for $\mathbf{5}$, which cannot be measured directly due to the electrochemical irreversibility of its oxidation, can be estimated $\left(c a . \mathrm{E}_{1 / 2}=0.00 \mathrm{~V}\right.$ vs. $\left.\mathrm{FcH}\right)$ from the experimental anionic peak potential obtained $\left(\mathrm{E}_{\mathrm{pa}}=0.05 \mathrm{~V} v s . \mathrm{FcH}\right)$. The differences between 
calculated (calc) and experimental (exp) $E_{1 / 2}$ values for both species $6\left(E_{1 / 2(c a l c)}-E_{1 / 2(\exp )}=\right.$ $0.22 \mathrm{~V})$ and $\operatorname{RuCp}_{2}\left(\mathrm{E}_{1 / 2(\mathrm{calc})}-\mathrm{E}_{1 / 2(\exp )}=0.25 \mathrm{~V}\right)$, are consistent with the electrochemical value estimated for $5\left(E_{1 / 2(\text { calc })}-E_{1 / 2(\text { estimated })}=0.25\right.$ V) (see Figure 12).

The effect of tilt upon the energies of neutral and oxidized metallocenes was also investigated. In the case of the iron compounds $\mathrm{FeCp}_{2}$ and oxidized $\mathrm{FeCp}_{2}{ }^{+}$, the energy increased markedly upon tilting. However the energy difference between the two species did not change greatly upon increasing $\alpha$ angle (Figure S8) ${ }^{62}$ until very large values $\left(\alpha>25^{\circ}\right)$. This is consistent with electrochemical studies of ferrocenophanes, which show that their redox potential is similar to that of ferrocene. ${ }^{23,17 \mathrm{c}} \mathrm{RuCp} 2$ likewise has a marked preference for the non-bent structure with $\alpha=0^{\circ}$. In contrast, $\mathrm{RuCp}_{2}{ }^{+}$barely increases in energy upon tilting, until $\alpha>20^{\circ}$, so that the cation lies lower in energy relative to the neutral species as the angle increases (Figure S9). These results are consistent with the observed reduction in oxidation potential for ruthenocene containing species as a function of tilt.

Analysis of the variation in orbital energies with $\alpha$ for $\mathrm{FeCp}_{2}$ (Figure S10) and $\mathrm{RuCp}_{2}$ (Figure S11) provided further insight into the experimental observations. For $\mathrm{FeCp}_{2}$ our calculations, which are in good agreement with previously reported studies into bent metallocenes, ${ }^{3}$ describe the mixing of one of the occupied $\mathrm{e}_{2}{ }^{\prime}$ orbitals with the $\mathrm{a}_{1}{ }^{\prime}$ orbital, affording two orbitals of the same symmetry. The upper of these two orbitals $\left(4 \mathrm{a}_{1}=\mathrm{HOMO}\right)$ is raised slightly in energy upon tilting $\left(\Delta \mathrm{E}=c a .39 .4 \mathrm{~kJ} \mathrm{~mol}^{-1}\right.$ at $\left.\alpha=30^{\circ}\right)$. Qualitatively similar results are reported for $\mathrm{RuCp}_{2}$, however in this case, the $4 \mathrm{a}_{1}$ orbital is raised significantly in energy upon distortion of the metallocene to even modest tilt angles $(\Delta \mathrm{E}=c a$. $99.8 \mathrm{~kJ} \mathrm{~mol}^{-1}$ at $\alpha=30^{\circ}$ ). These differences can be used as a rationale for the observed electrochemical properties, and thus facile removal of an electron from the $4 \mathrm{a}_{1}$ HOMO in tilted ruthenocenophanes is achieved relative to their Fe analogues. 


\section{CONCLUSIONS}

In summary, the redox properties of ruthenocenophanes have been studied, representing a rare investigation into the electron transfer chemistry of non-iron metallocenophanes. Unlike the analogous metallocenophanes of $\mathrm{Fe}$ and $\mathrm{Co}$, which undergo reversible one-electron oxidations, removal of an electron from dicarba[2]ruthenocenophane $\mathbf{5}$ afforded dicationic dimer 8 through metal-metal bond formation. To the best of our knowledge, this is the first example of metal-metal bond formation between strained $[n]$ metallocenophanes, resulting in one of the few examples of a ligand-unsupported $\mathrm{Ru} \mathrm{u}^{\mathrm{III}}-\mathrm{R} \mathrm{u}^{\mathrm{III}}$ bond. The reactivity of dimer 8 has been explored and, through the reaction with thiram, unusual dimer 9 has been isolated. The formation of dimer 9 from $\mathbf{8}$ provides a rare example of a $\eta^{5}-\eta^{3}$ crystallographically characterized haptotropic ring slip for a cyclopentadienyl ligand, and an apparent $2+2$ dimerization of the resulting alkene. Species $\mathbf{1 5}$ and 16, analogs of intermediate $\mathbf{1 0}$ in the postulated mechanism of formation of $\mathbf{9}$, were synthesized from the reaction of $\mathbf{8}$ with dichalcogenides $\mathrm{PhE}-\mathrm{EPh}(\mathrm{E}=\mathrm{S}, \mathrm{Se})$.

The redox properties of less strained tricarba[3]ruthenocenophane $\mathbf{6}$ were also investigated and found to show some similarities to those of $\mathbf{5}$, with $\mathrm{Ru}-\mathrm{Ru}$ bond formation affording dimer 17 upon oxidation. However, evidence supporting a lower propensity for dimerization of less tilted cation $\mathbf{6}^{+}$was also detected, including electrochemical reversibility under certain conditions and the further reactivity modes of $\mathbf{6}^{+}$reported at ambient temperatures.

In line with these observations, computational studies revealed that the propensity for dimerization of ruthenocenophanes increases with increasing tilt angle and also provided an explanation for the lower oxidation potential for [2]ruthenocenophane 5 relative to [3]ruthenocenophane 6. 
Future work in this area will investigate the influence of ring-tilt on the redox chemistry of other metallocenophanes and related species, in addition to investigations of the unusual $\eta^{5}-\eta^{3}$ haptotropic ring slip and other reactivity modes at the Ru metal center.

\section{ASSOCIATED CONTENT}

\section{Supporting Information}

Experimentals, additional figures, crystallographic details, computational details. This material is available free of charge via the Internet at http://pubs.acs.org

\section{AUTHOR INFORMATION}

\section{Corresponding Author}

Ian.Manners@bristol.ac.uk

William.Geiger@uvm.edu

Jeremy.Harvey@bristol.ac.uk

\section{Present Addresses}

Joe B. Gilroy

Department of Chemistry

University of Western Ontario

1151 Richmond Street

London, ON, Canada, N6A 5B7

Kevin Lam

Nazarbayev University

School of Science and Technology

53 Kabanbay Batyr Ave, Block 7, Office 7107

010000 - Astana - Republic of Kazakhstan.

The authors declare no competing financial interests. 


\section{ACKNOWLEDGMENT}

We thank the EPSRC for financial support (A.D.R), the Natural Sciences and Engineering Research Council of Canada and the European Union Marie Curie Actions Program for postdoctoral fellowships (J.B.G.). Work at the University of Vermont was generously supported by the National Science Foundation, CHE-1212339.

\section{REFERENCES}

(1) a) Pannell, K. H.; Dementiev, V. V.; Hong, L.; Cervantes-Lee, F.; Nguyen, M. T.; Diaz, A. F. Organometallics 1994, 13, 3644; b) Herbert, D. E.; Mayer, U. F. J.; Manners, I. Angew. Chem. Int. Ed. 2007, 46, 5060; c) Khramov, D. M.; Rosen, E. L.; Lynch, V. M.; Bielawski, C. W. Angew. Chem. Int. Ed. 2008, 47, 2267; d) Moser, C.; Belaj, F.; Pietschnig, R. Chem. Eur. J. 2009, 15, 12589; e) Arnold, T.; Braunschweig, H.; Gross, M.; Kaupp, M.; Müller, R.; Radacki, K. Chem. Eur. J. 2010, 16, 3014; f) Bagh, B.; Gilroy, J. B.; Staubitz, A.; Müller, J. J. Am. Chem. Soc. 2010, 132, 1794; g) Bagh, B.; Schatte, G.; Green, J. C.; Müller, J. J. Am. Chem. Soc. 2012, 134, 7924; h) Musgrave, R. A.; Russell, A. D.; Manners, I. Organometallics 2013, 32, 5654; i) Sadeh, S.; Schatte, G.; Müller, J. Chem. Eur. J. 2013, 19, 13408.

(2) a) Berenbaum, A.; Manners, I. Dalton Trans. 2004, 2057; b) Elschenbroich, C.; Paganelli, F.; Nowotny, M.; Neumüller, B.; Burghaus, O. Z. Anorg. Allg. Chem. 2004, 630, 1599; c) Tamm, M.; Kunst, A.; Bannenberg, T.; Herdtweck, E.; Sirsch, P.; Elsevier, C. J.; Ernsting, J. M. Angew. Chem. Int. Ed. 2004, 43, 5530; d) Chadha, P.; Dutton, J. L.; Sgro, M. J.; Ragogna, P. J. Organometallics 2007, 26, 6063; e) Lund, C. L.; Schachner, J. A.; Quail, J. W.; Müller, J. J. Am. Chem. Soc. 2007, 129, 9313; f) Braunschweig, H.; Kaupp, M.; Adams, C. J.; Kupfer, T.; Radacki, K.; Schinzel, S. J. Am. Chem. Soc. 2008, 130, 11376; g) Tamm, M. 
Chem. Commun. 2008, 3089; h) Braunschweig, H.; Kupfer, T. Acc. Chem. Res. 2010, 43, 455.

(3) Green, J. C. Chem. Soc. Rev. 1998, 27, 263.

(4) a) Finckh, W.; Tang, B. Z.; Foucher, D. A.; Zamble, D. B.; Ziembinski, R.; Lough, A. J.; Manners, I. Organometallics 1993, 12, 823; b) Sharma, H. K.; Cervantes-Lee, F.; Mahmoud, J. S.; Pannell, K. H. Organometallics 1999, 18, 399.

(5) a) Bellas, V.; Rehahn, M. Angew. Chem. Int. Ed. 2007, 46, 5082; b) Whittell, G. R.; Hager, M. D.; Schubert, U. S.; Manners, I. Nature Mater. 2011, 10, 176.

(6) a) Ginzburg, M.; MacLachlan, M. J.; Yang, S. M.; Coombs, N.; Coyle, T. W.; Raju, N. P.; Greedan, J. E.; Herber, R. H.; Ozin, G. A.; Manners, I. J. Am. Chem. Soc. 2002, 124, 2625; b) Lu, J. Q.; Kopley, T. E.; Moll, N.; Roitman, D.; Chamberlin, D.; Fu, Q.; Liu, J.; Russell, T. P.; Rider, D. A.; Manners, I.; Winnik, M. A. Chem. Mater. 2005, 17, 2227.

(7) a) Cheng, J. Y.; Ross, C. A.; Chan, V. Z.-H.; Thomas, E. L.; Lammertink, R. G. H.; Vancso, G. J. Adv. Mater. 2001, 13, 1174; b) Korczagin, I.; Lammertink, R. G. H.; Hempenius, M. A.; Golze, S.; Vancso, G. J. Adv. Polym. Sci. 2006, 200, 91; c) Chuang, V. P.; Gwyther, J.; Mickiewicz, R. A.; Manners, I.; Ross, C. A. Nano. Lett. 2009, 9, 4364.

(8) Puzzo, D. P.; Arsenault, A. C.; Manners, I.; Ozin, G. A. Angew. Chem. Int. Ed. 2009, 48, 943.

(9) a) Espada, L.; Pannell, K. H.; Papkov, V.; Leites, L.; Bukalov, S.; Suzdalev, I.; Tanaka, M.; Hayashi, T. Organometallics 2002, 21, 3758; b) Kulbaba, K.; Cheng, A.; Bartole, A.; Greenberg, S.; Resendes, R.; Coombs, N.; Safa-Sefat, A.; Greedan, J. E.; Stover, H. D. H.; Ozin, G. A.; Manners, I. J. Am. Chem. Soc. 2002, 124, 12522; c) Ma, Y.; Dong, W.-F.; Hempenius, M. A.; Möhwald, H.; Vancso, G. J. Nature Mater. 2006, 5, 724.

(10) a) Papkov, V. S.; Gerasimov, M. V.; Dubovik, I. I.; Sharma, S.; Dementiev, V. V.; Pannell, K. H. Macromol. 2000, 33, 7107; b) Ma, Y.; Dong, W.-F.; Hempenius, M. A.; 
Möhwald, H.; Vancso, G. J. Angew. Chem. Int. Ed. 2007, 46, 1702; c) Rider, D. A.; Liu, K.;

Eloi, J. C.; Vanderark, L.; Yang, L.; Wang, J. Y.; Grozea, D.; Lu, Z. H.; Russell, T. P.; Manners, I. ACS Nano. 2008, 2, 263; d) Rupar, P. A.; Chabanne, L.; Manners, I. Science 2012, 337, 559 .

(11) a) Nelson, J. M.; Lough, A. J.; Manners, I. Angew. Chem. Int. Ed. 1994, 33, 989; b) Braunschweig, H.; Gross, M.; Radacki, K. Organometallics 2007, 26, 6688; c) Braunschweig, H.; Breher, F.; Kaupp, M.; Gross, M.; Kupfer, T.; Nied, D.; Radacki, K.; Schinzel, S. Organometallics 2008, 27, 6427; d) Braunschweig, H.; Gross, M.; Radacki, K.; Rothgaengel, C. Angew. Chem. Int. Ed. 2008, 47, 9979; e) Mayer, U. F. J.; Gilroy, J. B.; O'Hare, D.; Manners, I. J. Am. Chem. Soc. 2009, 131, 10382.

(12) Rulkens, R.; Lough, A. J.; Manners, I.; Lovelace, S. R.; Grant, C.; Geiger, W. E. J. Am. Chem. Soc. 1996, 118, 12683.

(13) a) Temple, K.; Jäkle, F.; Sheridan, J. B.; Manners, I. J. Am. Chem. Soc. 2001, 123, 1355;

b) Kumar, M.; Metta-Magana, A. J.; Pannell, K. H. Organometallics 2008, 27, 6457.

(14) Temple, K.; Jäkle, F.; Lough, A. J.; Manners, I. J. Chem. Soc. Dalton Trans 1997, 711.

(15) a) Herbert, D. E.; Gilroy, J. B.; Staubitz, A.; Haddow, M. F.; Harvey, J. N.; Manners, I. J. Am. Chem. Soc. 2010, 132, 1988; b) Gilroy, J. B.; Russell, A. D.; Stonor, A. J.; Chabanne, L.; Baljak, S.; Haddow, M. F.; Manners, I. Chem. Sci. 2012, 3, 830.

(16) a) Finckh, W.; Tang, B. Z.; Lough, A. J.; Manners, I. Organometallics 1992, 11, 2904; b) Herberhold, M.; Steffl, U.; Milius, W.; Wrackmeyer, B. Angew. Chem. Int. Ed. 1997, 36, 1508; c) Bera, H.; Braunschweig, H.; Oechsner, A.; Seeler, F.; Sigritz, R. J. Organomet. Chem. 2010, 695, 2609.

(17) a) Tanabe, M.; Vandermeulen, G. W. M.; Chan, W. Y.; Cyr, P. W.; Vanderark, L.; Rider, D. A.; Manners, I. Nature Mater. 2006, 5, 467; b) Herbert, D. E.; Gilroy, J. B.; Chan, W. Y.; Chabanne, L.; Staubitz, A.; Lough, A. J.; Manners, I. J. Am. Chem. Soc. 2009, 131, 
14958; c) Herbert, D. E.; Mayer, U. F. J.; Gilroy, J. B.; López-Gómez, M. J.; Lough, A. J.; Charmant, J. P. H.; Manners, I. Chem. Eur. J. 2009, 15, 12234.

(18) a) Mizuta, T.; Imamura, Y.; Miyoshi, K. J. Am. Chem. Soc. 2003, 125, 2068; b) Imamura, Y.; Kubo, K.; Mizuta, T.; Miyoshi, K. Organometallics 2006, 25, 2301; c) Herbert, D. E.; Tanabe, M.; Bourke, S. C.; Lough, A. J.; Manners, I. J. Am. Chem. Soc. 2008, 130, 4166.

(19) Masson, G.; Herbert, D. E.; Whittell, G. R.; Holland, J. P.; Lough, A. J.; Green, J. C.; Manners, I. Angew. Chem. Int. Ed. 2009, 48, 4961.

(20) a) Hashidzume, K.; Tobita, H.; Ogino, H. Organometallics 1995, 14, 1187; b) Schaper, F.; Wrobel, O.; Schwörer, R.; Brintzinger, H. H. Organometallics 2004, 23, 3552.

(21) Connelly, N. G.; Geiger, W. E. Chem. Rev. 1996, 96, 877.

(22) Durkee, D. A.; Eitouni, H. B.; Gomez, E. D.; Ellsworth, M. W.; Bell, A. T.; Balsara, N. P. Angew. Chem. Int. Ed. 2005, 17, 2003.

(23) a) Pudelski, J. K.; Foucher, D. A.; Honeyman, C. H.; Lough, A. J.; Manners, I.; Barlow, S.; O'Hare, D. Organometallics 1995, 14, 2470; b) Rulkens, R.; Gates, D. P.; Balaishis, D.; Pudelski, J. K.; McIntosh, D. F.; Lough, A. J.; Manners, I. J. Am. Chem. Soc. 1997, 119, 10976.

(24) a) Hill, M. G.; Lamanna, W. M.; Mann, K. R. Inorg. Chem. 1991, 30, 4687; b) Trupia, S.; Nafady, A.; Geiger, W. E. Inorg. Chem. 2003, 42, 5480; c) Banks, C. E.; Robinson, K. L.; Laing, H.-P.; Meredith, A. W.; Lawrence, N. S. Electroanal. 2007, 19, 555; d) Swarts, J. C.; Nafady, A.; Roudebush, J. H.; Trupia, S.; Geiger, W. E. Inorg. Chem. 2009, 48, 2156; e) Rogers, E. I.; Lawrence, N. S.; Compton, R. G. J. Electroanal. Chem. 2011, 657, 144.

(25) Russell, A. D.; Gilroy, J. B.; Lam, K.; Haddow, M. F.; Harvey, J. N.; Geiger, W. E.; Manners, I. Chem. Eur. J. 2012, 18, 8000.

(26) Geiger, W. E.; Barrière, F. Acc. Chem. Res. 2010, 43, 1030. 
(27) To establish the chemical reversibility of the synthesis of dimer $\mathbf{8}$, reduction with an excess of decamethylcolbaltocene in $\mathrm{CD}_{3} \mathrm{NO}_{2}$ was studied. ${ }^{1} \mathrm{H}$ NMR spectroscopic analysis revealed complete conversion of dimer $\mathbf{8}$ to the precursor dicarba[2]ruthenocenophane $\mathbf{5}$.

(28) The UV/Vis solvent cut-off for $\mathrm{Me}_{3} \mathrm{NO}_{2}$ was taken to be $400 \mathrm{~nm}$. For details see: $\mathrm{G}$. W. C. Kaye, T. H. Laby, Tables of Physical and Chemical Constants, 16th ed., The National Physics Laboratory, Middlesex, 1995.

(29) a) Kadish, K. M.; Wang, L.-L.; Thuriere, A.; Van Caemelbecke, E.; Bear, J. L. Inorg. Chem. 2003, 42, 834; b) Kadish, K. M.; Garcia, R.; Phan, T.; Wellhoff, J.; Van Caemelbecke, E.; Bear, J. L. Inorg. Chem. 2008, 47, 11423.

(30) a) Warren, L. F.; Goedken, V. L. J. Chem. Soc., Chem. Commun. 1978, 909; b) Hursthouse, M. B.; Jones, R. A.; Abdul Malik, K. M.; Wilkinson, G. J. Am. Chem. Soc. 1979, $101,4128$.

(31) Droege, M. W.; Harman, W. D.; Taube, H. Inorg. Chem. 1987, 26, 1309.

(32) The torsion angles between the four $\mathrm{Cp}$ centroid positions and the two Ru metal centres are as follows: $87.2(1), 88.9(1), 89.1(1), 94.8(1)^{\circ}$. The variation in these values reflects slight distortions in each dicarba[2]ruthenocenophane.

(33) a) Cotton, F. A.; Ren, T.; Eglin, J. L. J. Am. Chem. Soc. 1990, 112, 3439; b) Zuo, J.-L.; Herdtweck, E.; Kühn, F. E. J. Chem. Soc., Dalton Trans. 2002, 1244; c) Angardis, P. In Multiple Bonds Between Metal Atoms; 3rd ed.; Cotton, F. A., Murillo, C. A., Walton, R. A., Eds.; Springer Science and Business Media, Inc.: New York, 2005, p 377; d) Patra, S. K.; Sadhukhan, N.; Bera, J. K. Inorg. Chem. 2006, 45, 4007.

(34) a) Albers, M. O.; Liles, D. C.; Singleton, E.; Stead, J. E.; de V. Steyn, M. M. Organometallics 1986, 5, 1262; b) Shiu, K.-B.; Li, C.-H.; Chan, T.-J.; Peng, S.-M.; Cheng, M.-C.; Wang, S.-L.; Liao, F.-L.; Chiang, M. Y. Organometallics 1995, 14, 524; c) Funaioli, T.; Marchetti, F.; Fachinetti, G. Chem. Commun. 1999, 2043. 
(35) Mueller-Westerhoff, U. T.; Rheingold, A. L.; Swiegers, G. F. Angew. Chem. Int. Ed. $1992,31,1352$.

(36) The differences in the $\alpha$ angles between the two dicarba[2]ruthenocenophane units in dimer $\mathbf{8}$ appear to arise due to crystal packing effects.

(37) a) Cullen, W. R.; Talaba, A.; Rettig, S. J. Organometallics 1992, 11, 3152; b) Nishibayashi, Y.; Imajima, H.; Onodera, G.; Inada, Y.; Hidai, M.; Uemura, S. Organometallics 2004, 23, 5100; c) Phuay, E.; Tay, L.; Kuan, S. L.; Leong, W. K.; Goh, L. Y. Inorg. Chem. 2007, 46, 1440; d) Miyake, Y.; Endo, S.; Yuki, M.; Tanabe, Y.; Nishibayashi, Y. Organometallics 2008, 27, 6039.

(38) a) Huttner, G.; Brintzinger, H. H.; Bell, L. G.; Friedrich, P.; Bejenke, V.; Neugebauer, D. J. J. Organomet. Chem. 1978, 145, 329; b) O'Connor, J. M.; Casey, C. P. Chem. Rev. 1987, 87, 307.

(39) Veiros, L. F. Organometallics 2000, 19, 5549.

(40) For species 9, which does not contain an olefinic ring fragment, the angle $\omega$ is between the planes formed from the $\mathrm{C}(3)-\mathrm{C}(4)-\mathrm{C}(5)$ and $\mathrm{C}(3)-\mathrm{C}(2)-\mathrm{C}(1)-\mathrm{C}(5)$ ring carbons.

(41) Raaij, v.; Zsolnai, L.; Huttner, G.; Brintzinger, H. H. Z. Anorg. Allg. Chem. 1989, 577, 217.

(42) Calhorda, M. J.; Gamelas, C. A.; Romão, C. C.; Veiros, L. F. Eur. J. Inorg. Chem. 2000, 2000,331 .

(43) Basolo, F.; Rerek, M. E. Organometallics 1983, 2, 372.

(44) Simanko, W.; Tesch, W.; Sapunov, V. N.; Mereiter, K.; Schmid, R.; Kirchner, K. Organometallics 1998, 17, 5674.

(45) Veiros, L. F.; Calhorda, M. J. Comment Inorg. Chem. 2001, 22, 375.

(46) Trapping of intermediate $\mathbf{1 1}$ was attempted through the reaction of an equimolar amounts of dimer $\mathbf{8}$ and thiram, in the presence of five equivalents of $\mathrm{PhC}(\mathrm{O}) \mathrm{C} \equiv \mathrm{C}(\mathrm{O}) \mathrm{Ph}$, at 
room temperature with stirring for 4 days. ${ }^{1} \mathrm{H}$ NMR spectroscopic analysis of the crude indicated conversion to dimer 9. Unreacted $\mathrm{PhC}(\mathrm{O}) \mathrm{C} \equiv \mathrm{C}(\mathrm{O}) \mathrm{Ph}$ was recovered upon attempted isolation of 9 through crystallization.

(47) a) Corey, E. J.; Bass, J. D.; LeMahieu, R.; Mitra, R. B. J. Am. Chem. Soc. 1964, 86, 5570; b) Huisgen, R.; Feiler, L. A.; Binsch, G. Chem. Ber. 1969, 102, 3460.

(48) Reaction of $\mathbf{8}$ with thiram to afford $\mathbf{9}$ was observed to proceed in the absence of light, suggesting that the reaction does not proceed via a photochemically induced $2+2$ cycloaddition mechanism.

(49) a) Pedersen, S. F.; Schrock, R. R.; Churchill, M. R.; Wasserman, H. J. J. Am. Chem. Soc. 1982, 104, 6808; b) Lutsenko, Z. L.; Aleksandrov, G. G.; Petrovskii, P. V.; Shubina, E. S.; Andrianov, V. G.; Struchov, Y. T.; Rubezhov, A. Z. J. Organomet. Chem. 1985, 281, 349; c) Dzwiniel, T. L.; Ektin, N.; Stryker, J. M. J. Am. Chem. Soc. 1999, 121, 10640; d) Dzwiniel, T. L.; Stryker, J. M. J. Am. Chem. Soc. 2004, 126, 9184.

(50) Salembier, H.; Mauldin, J.; Hammond, T.; Wallace, R.; Alqassab, E.; Hall, M. B.; Pérez, L. M.; Chen, Y.-J. A.; Turner, K. E.; Bockoven, E.; Brennessel, W.; Chin, R. M. Organometallics 2012, 31, 4838.

(51) Zhang, Q.-F.; Cheung, F. K. M.; Wong, W.-Y.; Williams, I. D.; Leung, W.-H. Organometallics 2001, 20, 3777.

(52) The new environments that were observed by ${ }^{1} \mathrm{H}$ NMR for the Cp protons displayed characteristic splittings observed for $[n]$ metallocenophanes such as $\mathbf{5}$ and $\mathbf{6}$, with triplets assignable to both the $\alpha$ and $\beta$-protons. This observation suggests that the $\eta^{5}-\eta^{3}$ haptotropic transformation of the $\mathrm{Cp}$ ring did not occur in this instance.

(53) Kamiyama, S.; Suzuki, T.; Kimura, T.; Kasahara, A. B. Chem. Soc. Jpn. 1978, 51, 909.

(54) Ohba, S.; Saito, Y.; Kamiyama, S.; Kasahara, A. Acta. Cryst. Sect. C. 1984, C40, 53. 
(55) After aniodic bulk electrolysis of 6 at $25{ }^{\circ} \mathrm{C}\left(\mathrm{E}_{\mathrm{appl}}=0.4 \mathrm{~V}\right)$, the cyclic voltammagram displayed peaks associated with the reduction of dimer $\mathbf{1 7}$ in addition to other unidentified oxidation products. Following bulk reduction $\left(\mathrm{E}_{\mathrm{appl}}=-0.7 \mathrm{~V}\right)$, the peak corresponding to the oxidation of $\mathbf{6}$ is reobserved, in addition to peaks assigned to unidentified byproducts. Contrastingly, when bulk the oxidation for $\mathbf{6}$ is conducted at $-20{ }^{\circ} \mathrm{C}$, the cyclic voltammogram is broader (potentially resulting from a slower electron transfer rate), however upon bulk reduction, electrochemical behaviour is identical to $\mathbf{6}$, suggesting no additional reactivity of cation $\mathbf{6}^{+}$occurs at reduced temperatures.

(56) Stability of monocation $\mathbf{6}^{+}$was found to be temperature dependant. When the reaction was conducted at room temperature, a complex mixture of products resulted from which the dimer could not be isolated. Conducting the reaction at $-20{ }^{\circ} \mathrm{C}$ afforded the dimer $\mathbf{1 7}$ in moderate yield.

(57) Single crystals of $\mathbf{1 7}$ were produced through slow cooling a $\mathrm{CH}_{3} \mathrm{NO}_{2} / \mathrm{Et}_{2} \mathrm{O}$ solution of $\mathbf{1 7}$ to $-40{ }^{\circ} \mathrm{C}$. Analysis by X-ray crystallography determined a monoclinic unit cell with the parameters of $\mathrm{a}=17.7253 \AA, \mathrm{b}=23.4512 \AA, \mathrm{c}=16.9187 \AA, \beta=101.653^{\circ}, \mathrm{V}=6887.80 \AA^{2}$. A structural solution was obtained in the monoclinic space group $C 2 / c$ and consists of 1 molecule of $\left[\mathrm{B}\left(\mathrm{C}_{6} \mathrm{~F}_{5}\right)_{4}\right]^{-}$crystallizing with $1 / 2$ molecule of $\mathbf{1 7}$ per asymmetric unit with solvent occupying the voids in the lattice. Both the solvent and $\mathbf{1 7}$ displayed serious molecular disorder making satisfactory refinement of $\mathbf{1 7}$ impossible and as such the full structure and analysis have not been included in the manuscript.

(58) The complexity of the spectrum obtained from in situ ${ }^{1} \mathrm{H}$ NMR spectroscopic analysis of the oxidation of $\mathbf{7}$, indicated that multiple products had been formed, presumably through decomposition of highly electrophilic $7^{+}$.

(59) Treatment of 7 with $\mathrm{Ag}\left[\mathrm{B}\left(\mathrm{C}_{6} \mathrm{H}_{3}\left(\mathrm{CF}_{3}\right)_{2}\right)_{4}\right]$ resulted in $\mathrm{Ag}$ metal precipitation from solution. However, in situ ${ }^{1} \mathrm{H}$ NMR spectroscopic analysis of the reaction did not display 
signals that could be assigned to any of the proton environments in 7 (or product(s) thereof), potentially due to the formation of a paramagnetic byproduct(s). Despite several attempts, no oxidation product could be crystalized. .

(60) Three potential structures for dimer $\mathbf{1 7}$ were found. The structures vary through the position of the central carbons of the tricarba bridges. Calculations for dimer $\mathbf{1 7} \mathbf{b}$ afforded the greatest $\mathrm{Ru}-\mathrm{Ru}$ bond enthalpy, and therefore this data is used as representative for dimer $\mathbf{1 7}$. See Figure S7 in the Supporting Information for more details.

(61) Calculations were performed employing the coordinates obtained for the geometry optimized structures of untilted $\mathrm{FeCp}_{2}$ and $\mathrm{RuCp}_{2}$ respectively $\left(\alpha=0^{\circ}\right)$. These structures were then tilted by the required $\alpha$ angle, the $C \mathrm{p}_{\text {centroid }}-\mathrm{M}-\mathrm{C} \mathrm{p}_{\text {centroid }}$ bond angle was constrained, and the calculations were performed. In addition, the same geometry optimized structures were employed as starting coordinates for the calculations for oxidized species $\mathrm{FeCp}_{2}{ }^{+}$and $\mathrm{RuCp}_{2}{ }^{+}$

(62) Two total energies were calculated for the oxidized species $\mathrm{FeCp}_{2}{ }^{+}$and $\mathrm{RuCp}_{2}{ }^{+}$as a function of $\alpha$, corresponding to removal of an electron from either the $4 \mathrm{a}_{1}$ or $2 \mathrm{~b}_{1}$ orbitals (derived from $\mathrm{e}_{2}$ ' upon tilting) (see Figures S8 and S9). As oxidation will likely remove an electron from the higher energy $4 \mathrm{a}^{1}$ orbital, these results are used for comparison. 


\section{TOC GRAPHIC}

Influence of Cyclopentadienyl Ring-Tilt on Electron Transfer Reactions: RedoxInduced Reactivity of Strained [2] and [3]Ruthenocenophanes

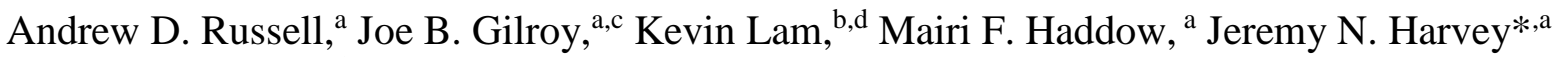
William E. Geiger*,b Ian Manners*,a

Strained ruthenocenophanes undergo dimerization following electron loss to form stable and isolable dicationic dimer complexes . These species undergo homolytic cleavage of the Ru$\mathrm{Ru}$ bond upon addition of radical sources, facilitating new reactivity modes including reactivity at the metal centre and an unusual $\eta^{5}-\eta^{3}$ haptrotropic $\mathrm{Cp}$ ring slip.

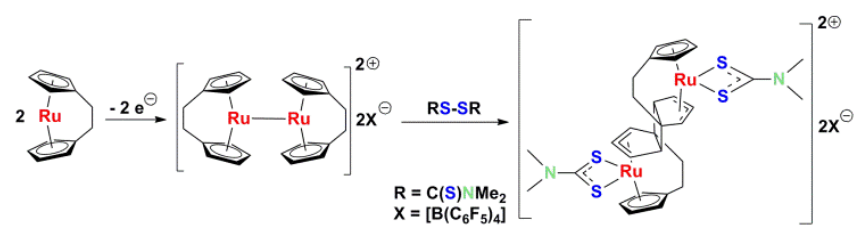

